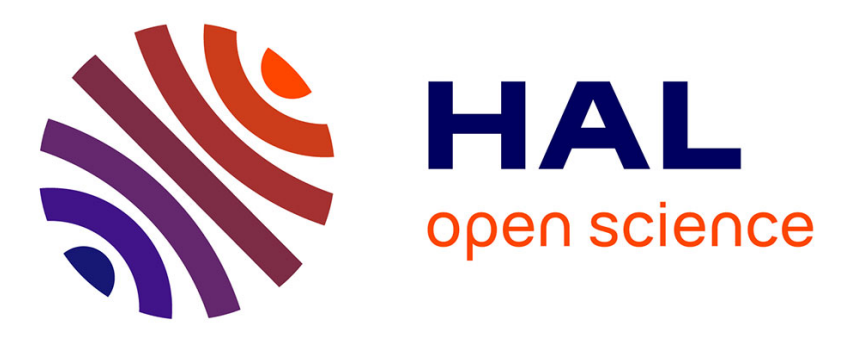

\title{
Phytolith indices as proxies of grass subfamilies on East African tropical mountains
}

\author{
Laurent Bremond, Anne Alexandre, Matthew J Wooller, Christelle Hély, \\ David Williamson, Peter A Schäfer, Amos Majule, Joel Guiot
}

\section{To cite this version:}

Laurent Bremond, Anne Alexandre, Matthew J Wooller, Christelle Hély, David Williamson, et al.. Phytolith indices as proxies of grass subfamilies on East African tropical mountains. Global and Planetary Change, 2008, 61 (3-4), pp.209 - 224. 10.1016/j.gloplacha.2007.08.016 . hal-01909600

\section{HAL Id: hal-01909600 \\ https://hal.science/hal-01909600}

Submitted on 14 Dec 2018

HAL is a multi-disciplinary open access archive for the deposit and dissemination of scientific research documents, whether they are published or not. The documents may come from teaching and research institutions in France or abroad, or from public or private research centers.
L'archive ouverte pluridisciplinaire HAL, est destinée au dépôt et à la diffusion de documents scientifiques de niveau recherche, publiés ou non, émanant des établissements d'enseignement et de recherche français ou étrangers, des laboratoires publics ou privés. 


\title{
Phytolith indices as proxies of grass subfamilies on East African tropical mountains
}

\author{
Laurent Bremond $^{\mathrm{a}, *}$, Anne Alexandre ${ }^{\mathrm{a}}$, Matthew J. Wooller ${ }^{\mathrm{b}}$, Christelle Hély ${ }^{\mathrm{a}}$, \\ David Williamson ${ }^{\mathrm{a}}$, Peter A. Schäfer ${ }^{\mathrm{c}}$, Amos Majule ${ }^{\mathrm{d}}$, Joël Guiot ${ }^{\mathrm{a}}$ \\ ${ }^{a}$ CEREGE, CNRS UMR 6635, Université Paul Cézanne Aix-Marseille III, Europôle Méditerranéen de l'Arbois, B.P. 80, F13545 Aix-en-Provence Cedex 04, France \\ ${ }^{\mathrm{b}}$ Water and Environmental Research Center and Institute of Marine Sciences, 461 Duckering Building, University of Alaska Fairbanks, AK 99775 , United States \\ ${ }^{\mathrm{c}}$ Conservateur des herbiers (MPU); Institut de Botanique-Université Montpellier 2; 163, rue A. Broussonet; F-34090 Montpellier, France \\ ${ }^{\mathrm{d}}$ Institute for Resource assessment, University of Dar el Salaam, p.o. box 35097, Dar el Salaam, Tanzania
}

Received 26 October 2006; accepted 23 August 2007

Available online 9 October 2007

\begin{abstract}
The main objective of this paper is to provide researchers that investigate fossil phytolith assemblages and model/data comparisons a new tool for estimating $\mathrm{C}_{3} / \mathrm{C}_{4}$ grass composition over time. We tested the reliability of modern soil phytolith assemblages and phytolith indices for tracing the dominance of different grass subfamilies and tree cover density. We analyzed modern soil phytolith assemblages from sites over elevation gradients on Mount Kenya (Kenya), Mount Rungwe and around Lake Masoko (southern Tanzania). These data were compared with available botanical data. A phytolith index named Ic, proved to be an effective proxy of the proportions of Pooideae, Arundinoideae and Bambusoideae grasses (mainly $\mathrm{C}_{3}$ grasses) versus Panicoideae grasses (mainly $\mathrm{C}_{4}$ grasses), increasing with elevation in East-Africa. When tropical mountains are covered by open habitats (e.g. grasses and shrublands), Ic should be a reliable proxy of the $\mathrm{C}_{3} / \mathrm{C}_{4}$ grass composition. These results highlight the value of the phytolith index Ic, when interpreting paleo-environmental records from tropical mountains, to: 1) better understand past local and regional $\mathrm{C}_{3} / \mathrm{C}_{4}$ grass distributions and associated climatic changes and 2) increase the set of $\mathrm{C}_{3} / \mathrm{C}_{4}$ data available for model/data comparisons.
\end{abstract}

(C) 2007 Elsevier B.V. All rights reserved.

Keywords: phytolith; paleovegetation; $\mathrm{C}_{3}, \mathrm{C}_{4}$; grass; woodland; East Africa

\section{Introduction}

In modern vegetation, where large variations in atmospheric partial pressure of $\mathrm{CO}_{2}\left(\mathrm{pCO}_{2}\right)$ relatively to $\mathrm{pO}_{2}$ do not occur, the crossover point favouring $\mathrm{C}_{3}$ over $\mathrm{C}_{4}$ grasses depends on atmospheric temperature, light availability, water availability and disturbances (Ehleringer et al., 1997; Sage et al., 1999). In tropical and subtropical regions, $\mathrm{C}_{4}$ grasses dominate up to $2000 \mathrm{~m}$ a.s.1., while $\mathrm{C}_{3}$ grasses are dominant at higher elevation

\footnotetext{
* Corresponding author. Now at Center of Bio-Archaeology and Ecology, EPHE, USTL, UMR5059 CNRS, Institut de Botanique, Université Montpellier 2, 163 rue Broussonet, F-34090 Montpellier, France.

E-mail address: laurent.bremond@univ-montp2.fr (L. Bremond).
}

(Livingstone and Clayton, 1980; Sage et al., 1999). At latitudes higher than $30-45^{\circ} \mathrm{C}_{3}$ grasses dominate (Cerling et al., 1997). However, plant metabolism also responds directly to atmospheric $\mathrm{pCO}_{2}$ relatively to $\mathrm{pO}_{2}$ and over time, ecosystems dominated by $\mathrm{C}_{4}$ grasses have been favoured under low $\mathrm{pCO}_{2}$ (i.e. $200 \mathrm{ppmV} \sim$ Last Glacial Maximum) although temperatures were relatively low (Cerling et al., 1997; Ehleringer et al., 1997; Collatz et al., 1998; Boom et al., 2002). At low $\mathrm{pCO}_{2}$, and high temperature, $\mathrm{C}_{4}$ grasses abundance and more generally $\mathrm{C}_{4}$ plants are also inversely correlated with soil moisture (e.g. Young and Young, 1983; Liu et al., 2005). Finally, the sensitivity of $\mathrm{C}_{3}$ and $\mathrm{C}_{4}$ grass and plants toward environmental factors is not well constrained and is likely to differ from one ecosystem to another and the climate pattern at key periods of time (e.g. LGM or Holocene warm period). 
Global vegetation models $(\mathrm{GVM})$ can predict $\mathrm{C}_{3} / \mathrm{C}_{4}$ grass distributions (e.g. Prentice et al., 1992; Haxeltine and Prentice, 1996; Sitch et al., 2003) that correctly describe vegetation at a global scale, but become less reliable at local or regional scales, especially when they are run using environmental conditions that are significantly different from today. One way to assess GVMs is to compare their outputs to palaeo-data. For instance, the BIOME 6000 project aimed to provide palaeodata from the mid-Holocene period as a benchmark to evaluate simulations with coupled climate-biosphere models, and thus to assess the extent of biogeophysical (vegetation-atmosphere) feedbacks in the global climate system (Prentice and Webb, 1998).

A few proxies can been used to infer past changes in the composition of $\mathrm{C}_{3}$ versus $\mathrm{C}_{4}$ grasses in vegetation. Fossil pollen assemblages are not suitable to determine these contributions as all grass (Poaceae) species produce pollen grains that are morphologically very similar. Stable carbon isotopic composition $\left(\delta^{13} \mathrm{C}\right)$ of total organic carbon (TOC) can be used to estimate the contribution of organic matter from plants using the $\mathrm{C}_{3}$ - or $\mathrm{C}_{4}$-photosynthetic pathways. However, the TOC of soils or sediments represents a complex mixture of diverse sources and ages (Krull et al., 2003a; Wooller et al., 2005). For instance, both terrestrial arboreal, non-arboreal (including some grasses) and freshwater aquatic components can have isotopic signatures indicative of the $\mathrm{C}_{3}$-pathway, which cannot be discriminated using sedimentary $\delta{ }^{13} \mathrm{C}_{\mathrm{TOC}}$ values. Isotopic analysis of specific compounds such as leaf wax $n$-alkanes can enhance the reconstruction, recording $\mathrm{C}_{3} / \mathrm{C}_{4}$ pathways among higher terrestrial plants (e.g. Boom et al., 2002; Ficken et al., 2002; Liu et al., 2005). However, none of these proxies are able to discriminate between $\mathrm{C}_{3}$ trees, shrubs and grasses which are adapted to very different bioclimatic conditions. $\delta^{13} \mathrm{C}$ analysis of grass epidermis (Beuning and Scott, 2002) or grass pollen grains (Descolas-Gros et al., 2001) are methods in their infancy. $\delta{ }^{13} \mathrm{C}$ analysis of occluded organic matter of grass phytoliths (Kelly et al., 1991; Fredlund, 1993; Kelly et al., 1998; McClaran and Umlauf, 2000; Krull et al., 2003b; Smith and White, 2004) is an additional promising tool. However, because phytolith organic compounds (mainly lignin) are heterogeneously depleted in ${ }^{13} \mathrm{C}$ relative to the whole plant tissue isotopic composition and calibration of the relationships between phytolith $\delta{ }^{13} \mathrm{C}$ values and $\mathrm{C}_{3} / \mathrm{C}_{4}$ grass abundance is still to be done. When they are preserved (highly subject to oxidation), sub-fossil grass cuticles retain micro-morphological features that permit identification to subfamily, supertribe, tribe and, in some instances, genus or species level (Wooller, 2002). However, up to now, only a few paleo-ecological studies have investigated this proxy (Mworia-Maitima, 1997; Wooller et al., 2000, 2003).

In addition to the proxies described above, phytoliths have been used to estimate the proportions of $\mathrm{C}_{3}$ and $\mathrm{C}_{4}$ grasses in past vegetation. Phytoliths are amorphous silica particles that precipitate in and/or between the cells of living plant tissues. Phytoliths are well preserved in oxidizing environments. Phytolith assemblages reflect well the relative proportions of three among five grass subfamilies, each of which is adapted to different environmental factors (Fredlund and Tieszen, 1994; Alexandre et al., 1997; Prebble et al., 2002; Scott, 2002; Bremond et al., 2005b; Albert et al., 2006): 1) Pooideae grasses use $\mathrm{C}_{3}$ photosynthesis and commonly grow at high elevations and high latitudes. 2) Panicoideae grasses are generally found in wet areas of low latitude and low elevation. Grasses in this subfamily mainly use $\mathrm{C}_{4}$ photosynthesis. However, in Africa $21 \%$ of the grass species in the Panicoideae subfamily, mostly growing under tropical forest canopies, use the $\mathrm{C}_{3}$ photosynthesis (Tieszen et al., 1979). 3) Chloridoideae grasses, which use $\mathrm{C}_{4}$ photosythesis, generally dominate dry areas at low latitudes and low elevation. The two other grass subfamilies are more ubiquitous. The Bambusoideae grasses and a majority of Arundinoideae grasses generally use $\mathrm{C}_{3}$ photosythesis.

Twiss (1992) first proposed that the proportion of $\mathrm{C}_{3}$ versus $\mathrm{C}_{4}$ grasses can be approximated by the ratio of phytoliths mainly produced by the Pooideae grass subfamily to the sum of phytoliths mainly produced by the Pooideae, Chloridoideae and Panicoideae subfamilies (Watson et al., 1985; Watson and Dallwitz, 1992). This ratio was termed by Twiss (1992) the Ic or climatic Index. Subsequently, Fredlund and Tieszen (1994) demonstrated a statistical relationship between modern phytolith assemblages and $\mathrm{C}_{3} / \mathrm{C}_{4}$ grass dominance in grasslands of the North American Great Plains. Phytolith assemblages from soils, buried soils, lake sediments, and marine cores were then used to reconstruct $\mathrm{C}_{3}$ versus $\mathrm{C}_{4}$ grass dominance in several areas (Fredlund and Tieszen, 1997; Baker et al., 2000; Blinnikov et al., 2002; Scott, 2002; Strömberg, 2002; Abrantes, 2003). However, as previously noted, $\mathrm{C}_{3}$-Panicoideae, $\mathrm{C}_{3}$ Bambusoideae and $\mathrm{C}_{3}$ and $\mathrm{C}_{4}$-Arundinoideae grasses may contribute to the overall phytolith production, and the relationship between $\mathrm{C}_{3} / \mathrm{C}_{4}$ grass abundance and Ic has to be regionally validated. Two other phytolith indices (Iph and D/P) have subsequently been proposed (Diester-Haass et al., 1973; Alexandre et al., 1997) and calibrated in term of proxies of short versus tall-grass dominance, grass evapotranspiration and tree cover density in tropical areas (Bremond et al., 2005a; Bremond et al., 2005b).

The aims of our study are: 1) to assess the reliability of phytolith assemblages and indices for tracing Pooideae, Panicoideae and Chloridoideae grass dominance, as well as tree cover density, in African tropical mountain areas, and 2) to discuss the potentials and limitations of Ic for tracing $\mathrm{C}_{3}$ versus $\mathrm{C}_{4}$ grasses proportions in tropical mountain areas. These data will provide researchers dealing with fossil phytolith assemblages and with model/data comparisons with such a new tool for estimating $\mathrm{C}_{3} / \mathrm{C}_{4}$ grass competition over time. Modern phytolith assemblages from soil humic horizons are compared with botanical data from a number of sites on Mt. Kenya, Mt. Rungwe (Tanzania) and around Lake Masoko (Tanzania). We choose to study soil phytolith assemblage because it is a function of plant biomass, phytolith production including multiplicity and redundancy patterns (Piperno and Pearsall, 1998), and phytolith selective dissolution in litter and soil (or taphonomy), processes that affect fossil phytolith assemblages. 


\section{Material and methods}

\subsection{Mount Kenya}

Mount Kenya is located on the equator $\left(0^{\circ} \mathrm{S} ; 37.1^{\circ} \mathrm{E}\right)$ in Kenya, East Africa (Fig. 1a). It is the second highest mountain in Africa (5199 $\mathrm{m}$ a.s.1.), and forms an isolated conical massif with a basal diameter of about $120 \mathrm{~km}$. The mountain was formed by volcanic activity during the Tertiary and Quaternary, mainly between 2.6 and 3.1 Myr BP although there have been more recent eruptions on the eastern side of the mountain until about 1 Myr BP (Tattersfield et al., 2001). Soils are developed on volcanic materials. The climate is characteristic of the inter-tropical convergence zone (ITCZ), with large diurnal temperature oscillations and small monthly variations during the course of the year. Two rainy seasons occur in March-May and October-November, when the heaviest precipitation $(>2500 \mathrm{~mm} / \mathrm{yr}$ ) falls at mid-elevations (2000-3000 m a.s.l.) on the southeastern flank of the mountain. Total precipitation declines with elevation above the tree line (located at $\sim 2900-3400 \mathrm{~m}$ a.s.l.) to $<900 \mathrm{~mm} / \mathrm{yr}$ above $4500 \mathrm{~m}$ a.s.1., where it mainly falls as snow (StreetPerrott et al., 2004). Vegetation fires at the end of the dry seasons reinforce the climatically induced vegetation zonation. Along Chogoria and Sirimon tracks (Wooller et al., 2001), the present-day vegetation shows marked altitudinal zonation (Fig. 1c1 and c2) where the basal plateau zone (disturbed tall grass savanna) is dominated by Themeda triandra Forsk. $\left(\mathrm{C}_{4}\right.$-Panicoideae) and other Panicoideae grasses (mainly $\mathrm{C}_{4}$ ) that frequently burn. This grassland grades up, on the north-western slope, into the Mountain forest belt $(1 ; \sim 1960-2500 \mathrm{~m}$ a.s.1.), occupying the wettest areas, which have a sparse presence of Panicoideae (essentially $\mathrm{C}_{3}$ under the forest), Arundinoideae (mainly $\left.\mathrm{C}_{3}\right)$, Bambusoideae $\left(\mathrm{C}_{3}\right)$ grasses and sedges. The Bamboo zone $(2 ; \sim 2450-2900 \mathrm{~m}$ a.s.1.) is dominated by the Bambusoideae grass Arundinaria alpina $\mathrm{K}$. Schum. The Hagenia-Hypericum zone (3; 2900-3000 m a.s.1.) is dominated by woody trees, shrubs, and some grasses (Panicoideae and Pooideae grasses; $\mathrm{C}_{4}$ and $\mathrm{C}_{3}$, respectively). The Ericaceous zone $(4 ; \sim 3000-3400 \mathrm{~m}$ a.s.l.) is dominated by woody shrubs and Pooideae grasses $\left(\mathrm{C}_{3}\right)$. Some patches of Panicoideae grasses $\left(\mathrm{C}_{4}\right)$ are located in the lower part of this zone. The Afroalpine zone $\left(5 ; \sim 3400-4200 \mathrm{~m}\right.$ a.s.1.) is dominated by Pooideae tussock grasses $\left(C_{3}\right)$ with some sedges. The Nival zone $(6 ; \sim 4200-$ $5199 \mathrm{~m}$ a.s.1.) presents isolated Pooideae grasses $\left(\mathrm{C}_{3}\right)$ in very sheltered areas. There is a gap in the forest on the northern flank of Mount Kenya, which corresponds to relatively low rainfall values. This forest gap may have originated as a result of disturbance (Wooller et al., 2000).

\subsection{Mount Rungwe}

Mount Rungwe is located at $9^{\circ} \mathrm{S}, 33^{\circ} \mathrm{E}$ in Tanzania, East Africa (Fig. 1a), from 1400 to $2960 \mathrm{~m}$ a.s.l. The mountain is a dormant volcano mainly built up of phonolitic trachyte lavas and tuffs, overlying a foundation of phonolites and basalts (Harkin, 1959). Soils are vitric andosols and Andosols with areas of Lithosols (F.A.O., 1998). Estimated rainfall ranges from $1550 \mathrm{~mm}$ to $2500 \mathrm{~mm} / \mathrm{yr}$ on the northern and southern slopes, respectively. Only one dry season occurs from June to October, with maximum estimated temperatures (at $\sim 1800-2000 \mathrm{~m}$ a.s.1.) of $20^{\circ} \mathrm{C}$ in October and a minimum of $9{ }^{\circ} \mathrm{C}$ in June and July (McKone, 1994, 1995, Rungwe Regional District, unpublished data).

The vegetation distribution on Mount Rungwe (Fig. 1d1 and d2) was investigated during sample collection and complemented with McKone's data (1994, 1995): A) Mountain forest is found at low elevations (1600 to $2200 \mathrm{~m}$ a.s.l.) on southern and western slopes. Pseudobromus sylvaticus $\left(\mathrm{C}_{3}\right.$-Pooideae) and Cyperus sp. were observed on the southern flank under dense forest canopy. On the northern flank, in open areas enclosed within the Mountain forest, tussock Schizachyrium brevifolium $\left(\mathrm{C}_{4}\right.$-Panicoideae) is dominant. B) Upper Mountain forest (2200 to $2500 \mathrm{~m}$ a.s.1.) shows typical fairly thick undergrowth and numerous lianas. Large stands of regenerating bamboo $\left(\mathrm{C}_{3}\right.$-Bambusoideae) are prominent in the southern and southwestern slopes. Short to medium sized grasses occur in small patches throughout the Upper Mountain forest. The dominant species from this zone is Arundinaria alpina $\left(\mathrm{C}_{3}\right.$-Bambusoideae). Pennisetum sp., and Andropogoneae sp. ( $\mathrm{C}_{4}$-Panicoideae $)$ are also present. C) Ericaceous belt develops at upper southern and southeastern elevations, between 2600 and $2800 \mathrm{~m}$ a.s.l., generally representative of a transitional zone between forest and upper grasslands. This zone is dominated by Erica arborea with fewer Protea sp., and low stature Hagenia abyssinica. D) Bushed grasslands occur above the forest, where the abundance of bushes decreases while the abundance of grasses increases with elevation. Dominant grasses are Andropogoneae sp. and Brachypodium flexum $\left(\mathrm{C}_{3}\right.$-Pooideae). E) Upper grasslands occur above $2500 \mathrm{~m}$ a.s.l., though the tree-line, subject to fires, varies from $2000 \mathrm{~m}$ a.s.l. in the southwest to $2800 \mathrm{~m}$ a.s.l. close to Rungwe Peak. Observed dominant grass species are Poa leptochlada A. Rich and Deschampsia flexuosa $\left(\mathrm{C}_{3}\right.$-Pooideae), and Pentaschistis chrysurus $\left(\mathrm{C}_{3}\right.$-Arundinoideae or Danthonioideae) (GPWG, 2001).

\subsection{Lake Masoko area}

Modern soil samples were collected around Lake Masoko ( $9^{\circ} 20^{\prime} \mathrm{S}, 33^{\circ} 45^{\prime} \mathrm{E} ; 760 \mathrm{~m}$ a.s.1.), ca. $20 \mathrm{~km}$ south of Mount Rungwe (Fig. 1a and b). The crater consists of a ca. 50 kyr-old tuff ring occupied by well-drained ash soils (mollic andosols). The mean annual rainfall $(\sim 2500 \mathrm{~mm})$ does not significantly differ from the Rungwe higher altitude areas, but the local mean annual temperature (and evaporation) is higher and shows lower seasonal amplitude $\left(\sim 23-27^{\circ} \mathrm{C}\right)$ (Williamson et al., 1999; Garcin et al., 2006). The vegetation is classified by White (1983) as a "wetter Zambezian Miombo woodlands" (semi-deciduous forest). Six samples were 

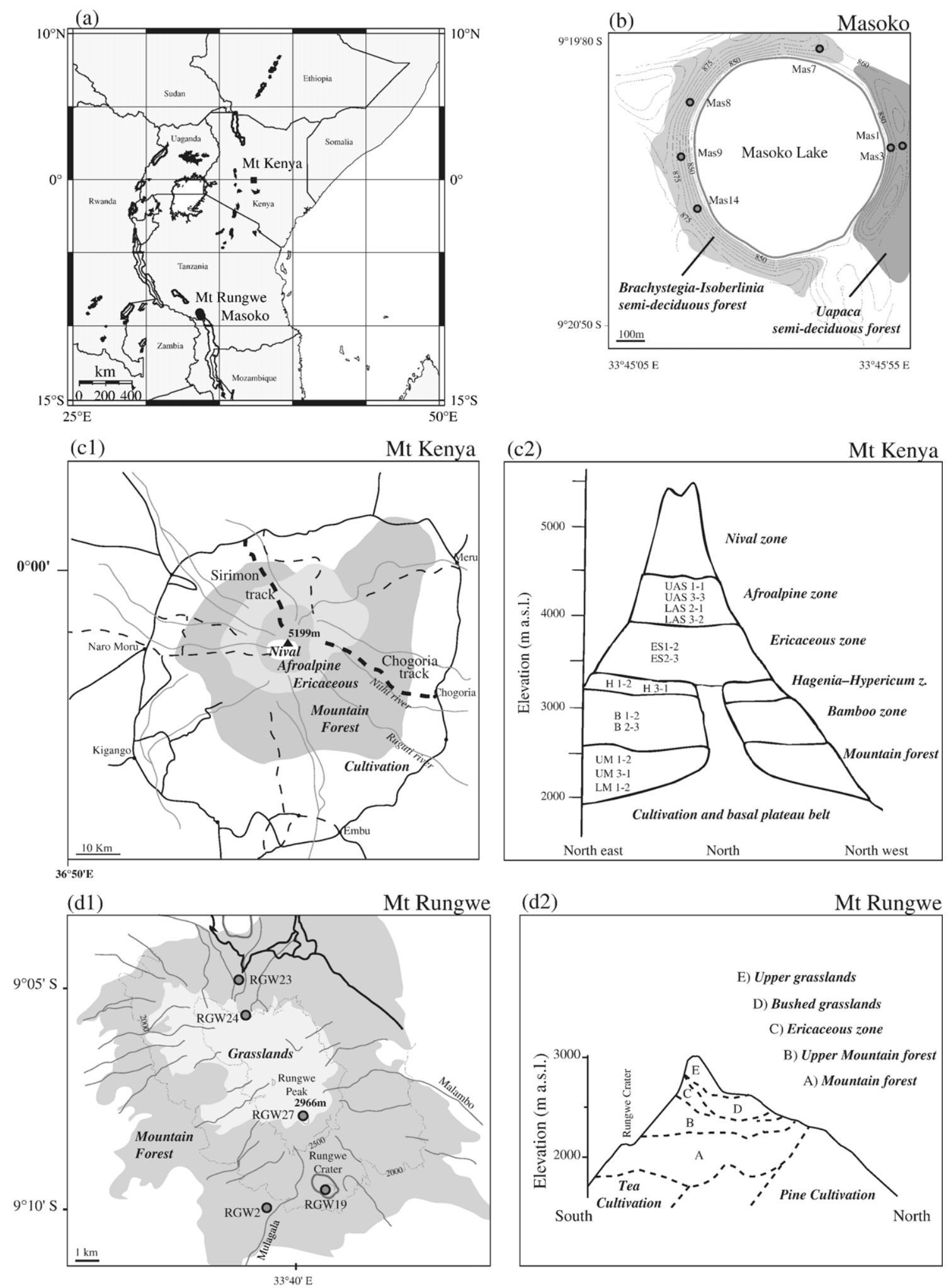

Fig. 1. (a) Location of the East-African sites used in this study. (b) Vegetation and location of the sampled sites in the Masoko lake catchment area. (c1) Location of the Chogoria and Sirmon Tracks (this study) on Mount Kenya. Vegetation belts are mapped after Wass (1995) and Ficken et al. (2002). (c2) Location of sites on Mount Kenya (as listed in Table 1 after Wooller et al. 2000) used in this study. (d1) Location of sites sampled on Mount Rungwe. (d2) Vegetation belts and distribution investigated during sample collection and after McKone, 1994 and 1995.

collected under the semi-deciduous forest dominated by Uapaca (MAS 1, 3 and 9), and under the semi-deciduous forest dominated by Brachystegia and Isoberlinia (MAS 7, 8 and 14). The grass cover consists of Panicum sp., Imperata cylindrica, Hyparrhenia sp. $\left(\mathrm{C}_{4}\right.$-Panicoideae $)$ and Eragrostis congesta $\left(\mathrm{C}_{4}\right.$-Chloridoideae). 


\subsection{Phytolith samples (Table 1)}

Samples from Mount Kenya were collected in 1997 (January and February) along the Chogoria and Sirimon tracks, from 1900 to $4200 \mathrm{~m}$ a.s.l. (Wooller, 1999). Phytolith sampling was carried out using samples from sites for which botanical data were available (Wooller et al., 2001). Several individual sub-samples of the soil humic horizon (1 cm in depth after litter removal) were collected from the areas surveyed for their vegetation composition (Wooller et al., 2001). Quadrats $5 \times 5 \mathrm{~m}$ were sampled in vegetation zones with sparse ground layer (mountain forest zones and bamboo zone), whilst $2 \times 2 \mathrm{~m}$ quadrats were sampled in vegetation with a dense ground layer (Hagenia-Hypericum zone, ericaceous zone, alpine zone). Thirteen soil surface samples were treated for phytolith extraction including, from lower to higher elevation, three samples from the lower and upper parts of the Mountain forest (LM 1-2, UM 3-1, UM 2-1), two samples from the Bamboo zone (B 2-3, B 1-2), two from the Hagenia-Hypericum zone (H 1-2, H 3-1), two from the Ericaceous zone (ES 2-3, ES 1-2) and four samples from the lower (LAS 3-2, LAS 2-1) and upper (UAS 3-3, UAS 1-1) parts of the Afroalpine zone.

Soil samples from Mount Rungwe (from 2150 to $2966 \mathrm{~m}$ a.s.l.) and the catchment of Lake Masoko (840-900 m a.s.1.) were collected in November 2001, over homogeneous areas of about $50 \mathrm{~m}^{2}$. Eleven soil samples were collected including, on Mount Rungwe: one sample from mountain forest (RGW 2); one sample from the edge of an enclosed grassland in the Mountain forest (RGW 19); one sample from a short grassland occurring in small patches throughout the Upper Mountain forest (RGW 23); one sample from the boundary of the Ericaceous belt in the bushed grassland (RGW 24); one sample from the upper grassland (RGW 27); and surrounding Lake Masoko: three samples from the Uapaca semi-deciduous forest (MAS 1, 3, 7); and three samples from the Brachystegia-Isoberlinia semi-deciduous forest (MAS 8, 9, 14).

\subsection{Phytolith extraction and counting}

Phytoliths were extracted from $20 \mathrm{~g}$ of dry soil, representing a mixing of all the sub-samples, slightly crushed, sieved at $2 \mathrm{~mm}$ and processed through the following stages (Kelly, 1990): 1) grinding; 2) dissolution of carbonates, using $\mathrm{HCl}(3 \%$ ); 3 ) removal of iron oxides using sodium citrate $\left(\mathrm{C}_{6} \mathrm{H}_{5} \mathrm{Na}_{3} \mathrm{O}_{7}\right)$ and sodium dithionite $\left.\left(\mathrm{Na}_{2} \mathrm{O}_{4} \mathrm{~S}_{2}, \mathrm{H}_{2} \mathrm{O}_{2}\right) ; 4\right)$ oxidation of organic matter using $\mathrm{H}_{2} \mathrm{O}_{2}(30 \%)$ heated at $90{ }^{\circ} \mathrm{C}$ until reaction subsides; 5) sieving at $60 \mu \mathrm{m}$; 6) clay removal; and 7) densimetric separation of phytoliths in a $\mathrm{ZnBr}_{2}$ heavy liquid $(\mathrm{d}=2.3)$ (Kelly, 1990). The recovered fraction, including opal phytoliths, a few diatoms and volcanic ashes from each sample, was mounted on microscope slides in glycerin for 3D observation and in Canada Balsam for counting at $600 \mathrm{X}$ magnification. Amorphous silica particles other than classified phytolith types were not counted. More than 300 phytoliths with a diameter greater than $5 \mu \mathrm{m}$ and with taxonomic significance were counted per sample. Double counting was conducted on 3 slides and gave an error of $5 \%$ (s.d.).

\subsection{Phytolith types: classification}

Phytoliths are classified according to Twiss et al. (1969) and Twiss (1992) and the descriptions of phytolith shapes described by Mulholland (1989), Fredlund and Tieszen (1994), Kondo et al. (1994), Alexandre et al. (1997) and named after the International Code for Phytolith Nomenclature 1.0 (Madella et al., 2005) (Fig. 2). Twenty-four modern phytolith assemblages were investigated for this study. Thirteen phytolith types were categorized: The abundance of six phytolith types formed inside the short cells of grass epidermis allows three among five of the grass subfamilies to be distinguished. The Cross (1) and Bilobate short cell (2) phytolith types occur dominantly in the Panicoideae grass subfamily (Twiss et al., 1969; Mulholland, 1989; Fredlund and Tieszen, 1994; Kondo et al., 1994). The Saddle (3) type is produced in high proportion by the Chloridoideae grass subfamily (Twiss et al., 1969; Mulholland, 1989; Fredlund and Tieszen, 1994; Kondo et al., 1994). The Rondel (4) type (Mulholland, 1989) corresponds to the pooid type proposed by Twiss et al. (1969) and to the conical, keeled and pyramidal types named by Fredlund and Tieszen (1994). The Trapeziform polylobate short cell (5) type is named the crenate type by Fredlund and Tieszen (1994). Both Rondel and Trapeziform polylobate short cell types are mainly produced by the Pooideae subfamily (Twiss et al., 1969). The Trapeziform short cell type (6) is also produced by Pooideae grasses (Twiss et al., 1969; Mulholland, 1989; Kondo et al., 1994).

Among the two other grass subfamilies, the Bambusoideae grasses produce several phytolith types described above and especially both Rondel and Saddle types (Brown, 1984; Watson et al., 1985; Ollendorf, 1987; Mulholland, 1989). Investigating several American grass species, Piperno and Pearsall (1998) presented a phytolith type (Collapsed saddle) as common in subtribes Guaduineae and Chusqueinae. The Collapsed saddle type was used by Stromberg (2004) as a key indicator of Bamboo in the American Great Plains. Kondo et al. (1994), Lu et al. (1995) and Lu and Liu (2003), investigating some grass species from New Zealand, China and USA presented a "long saddle" type as exclusively produced by the Bambusoideae species they studied. However, there is no evidence of a single type or several phytolith types that are diagnostic of (that is to say "only present in", according to the ICPN 1.0 (Madella et al., 2005)) the whole Bambusoideae subfamily and taxa (mainly from the tribe Bambuseae) from African bamboo zones of high elevation.

Piperno and Pearsall (1998) also showed that individual genera in the Arundinoideae subfamily are marked by highly divergent sets of phytoliths that may exhibit Panicoideae, Chloridoideae, or Pooideae tendencies (Kondo et al., 1994). 


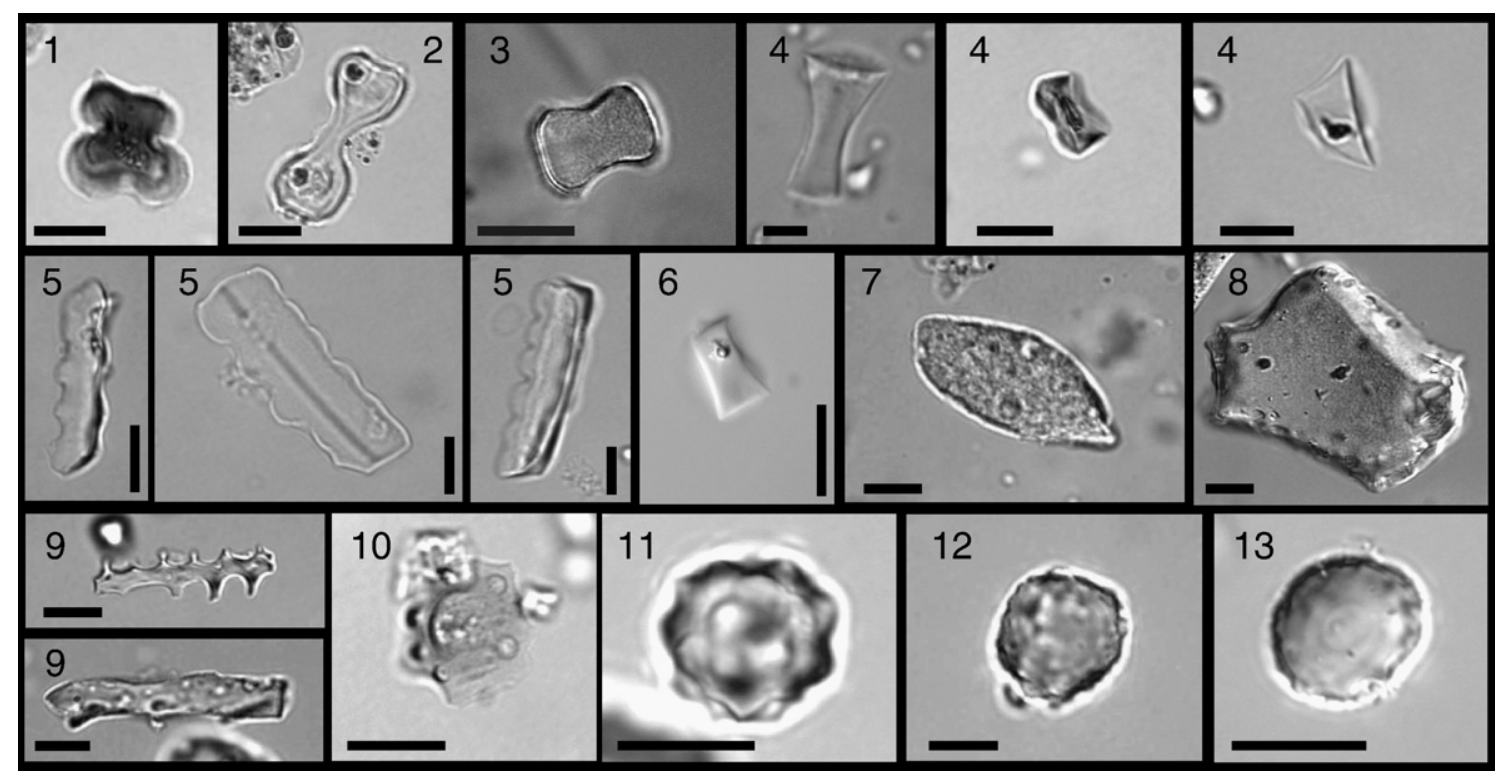

Fig. 2. Microphotographs representing 11 types of classified phytoliths counted in this study; Scale bar=10 $\mu$ m: (1) Cross, (2) Bilobate short cell, (3) Saddle, (4) Rondel, (5) Trapeziform polylobate short cell, (6) Trapeziform short cell, (7) Acicular hair cell, (8) parallepiped Bulliform cells, (9) Elongate (psilate and echinate elongate types are merged in this same group), (10) Papillae, (11) Globular echinate, (12) Globular granulate, (13) Globular psilate.

Carter (2002) specified that Arundinoideae grasses from New Zealand mainly produce the Rondel type also produced in abundance by Pooideae grasses. Here again there are no phytolith types diagnostic of the whole Arundinoideae subfamily.

Other phytolith types, produced in the epidermis of grasses can be diagnostic of the whole grass family. The Acicular hair cell (7) type originates from micro-hair or prickles (Palmer et al., 1985; Kaplan et al., 1992). Cuneiform and Parallepiped bulliform cells (8) phytolith types (Twiss et al., 1969; Kondo et al., 1994) are produced inside the bulliform-cells. The Elongate (9) type (Psilate and Echinate elongate types are merged in the same group) forms in the long-cells of the epidermis of grasses.

Four phytolith types produced by non-Poaceae taxa were counted in this study: the Papillae (10) type that is produced by Cyperaceae (sedge) (Le Cohu, 1973; Ollendorf, 1987; Kondo et al., 1994; Wallis, 2003); the Globular echinate (11) type that is produced by Palmae (Kondo et al., 1994; Runge, 1999; Runge and Fimbel, 1999; Vrydaghs and Doutrelepont, 2000); the Globular granulate (12) type that is produced in the wood of tropical trees and shrubs (ligneous dicotyledon) (Scurfield et al., 1974; Kondo et al., 1994); and the Globular psilate (13) type that may have several origins according to Kondo et al. (1994). This final type is produced in the epidermis of leaves and in parenchyma cells of dicotyledons' twigs and wood. It has been recovered in small proportions from several tropical herbaceous monocots and in greater quantities from the leaves and seeds of a small number of tropical arboreal dicotyledons (Piperno, 1988). Fig. 2 shows photo-micrographs of the 13 phytolith types presented above.

\subsection{Phytolith indices}

In order to discuss the reliability of phytolith assemblages to trace vegetation features such as the dominant grass subfamily and tree cover density, three ratios (phytolith indices) of phytolith types with relevant taxonomic significance are calculated:

1) Ic is the percentage of short cell phytoliths, mainly produced by Pooideae relative to the sum of short cell phytoliths mainly produced by Pooideae, Chloridoideae and Panicoideae grasses (Twiss, 1992).

$$
\mathrm{Ic}(\%)=\frac{\text { Rondel }+ \text { Trapeziform polylobate }+ \text { Trapeziform short cell }}{\text { Rondel }+ \text { Trapeziform polylobate short cell }+ \text { Trapeziform short cell }+ \text { Saddle }+ \text { Cross }+ \text { Bilobate short cell }} \times 100
$$

Grass cover dominated by Pooideae grasses should produce a high Ic while grasslands dominated by Panicoideae and Chloridoideae grasses should yield a low Ic. However, as previously noted, abundance of Arundinoideae and Bambusoideae grasses that produce non-distinctive grass phytoliths may add statistical noise to Ic signal. 
2) Iph is the percentage of Chloridoideae short cell phytolith types relatively to the sum of Panicoideae and Chloridoideae short cell phytolith types (Diester-Haass et al. 1973).

$$
\operatorname{Iph}(\%)=\frac{\text { Saddle }}{\text { Saddle }+ \text { Cross }+ \text { Bilobate short cell }} \times 100
$$

Several studies demonstrated that Iph is a very good proxy of Chloridoideae versus Panicoideae (or $\mathrm{C}_{4}$-short versus $\mathrm{C}_{4}$-tall grasses) in the American Great Plains and in tropical savannas (Alexandre et al., 1997; Fredlund and Tieszen, 1997; Bremond et al., 2005b).

3) $\mathrm{D} / \mathrm{P}^{\circ}$ is the ratio of phytoliths diagnostic of tropical woody dicotyledons, versus short cell phytoliths diagnostic of grasses.

$$
D / P^{\circ}=\frac{\text { Globular granulate }}{\text { Bilobate short cell }+ \text { Cross }+ \text { Saddle }+ \text { Rondel }+ \text { Trapeziform polylobate short cell }+ \text { Trapeziform short cell }}
$$

A first $D / P$ index, including all Poaceae phytolith types in the denominator, was used by Alexandre et al. (1997) in West Africa to estimate tree cover density and was calibrated with the Leaf Area Index (LAI) in a forest-savanna transition in Cameroon (Bremond et al., 2005a). Poaceae phytolith types other than short cell types (Acicular hair cells, Elongate, Cuneiform and Parallepiped bulliform cells) are removed from the present ratio, renamed $\mathrm{D} / \mathrm{P}^{\circ}$, as their abundance may be environmentally controlled (Bremond et al., 2005b). Phytolith studies investigating temperate and in Mediterranean sites showed that the Globular granulate phytolith type is not ubiquitous in non-tropical trees (Delhon et al., 2003; Bremond et al., 2004; Strömberg, 2004). Finally, the reliability of the $D / P^{\circ}$ index to trace tree cover density is assumed for tropical areas of low elevation only.

\subsection{Vegetation survey on the north-western slope of Mount Kenya}

Surveys of grass species occurrence were made on 38 sites along the elevation gradient of the north-western and eastern slopes of Mount Kenya (Fig. 3). Three quadrats $(2 \times 2$ or $5 \times 5 \mathrm{~m})$ randomly placed at each site were investigated (Wooller et al., 2001). The 38 sites include the 13 sites sampled for phytolith extraction. One, 0 and 0.5 values were assigned to species present inside the quadrat, absent from the quadrat, and present close to but outside the quadrat, respectively (Fig. 3).

Changes in the ratio of Pooideae versus Panicoideae and Chloridoideae phytolith types or in the Ic index should be related to changes in the relative biomass of Pooideae versus Panicoideae and Chloridoideae grasses. However, as biomass data was not available for this study, Ic is here compared with a botanical index Ib, calculated from the statements of grass species occurrence (Fig. 3). Ib is the percentage of Pooideae, Bambusoideae and Arundinoideae species (which are exclusively $\mathrm{C}_{3}$-grasses in the studied area) relative to the sum of Pooideae, Arundinoideae, Bambusoideae, Panicoideae and Chloridoideae species $\left(\mathrm{C}_{3}-\right.$ and $\mathrm{C}_{4}$-grasses.

$$
\mathrm{Ib}(\%)=\frac{\text { Pooideae }+ \text { Arundinoideae }+ \text { Bambusoideae }}{\text { Pooideae }+ \text { Arundinoideae }+ \text { Panicoideae }+ \text { Chloridoideae }+ \text { Bambusoideae }} \times 100
$$

A photosynthetic pathway was attributed to each grass species listed in Fig. 3, on the basis of their $\delta^{13} \mathrm{C}$ value analyzed by Wooller (1999) and Wooller et al. (2001). Grass species are also gathered into both traditional and Grass Phylogeny Working Group (GPWG) subfamilies (GPWG, 2001). The GPWG classification takes into account grass biology and evolution (GPWG, 2001). The most significant changes brought by the GPWG classification are the breakup of the traditional Bambusoideae and Arundinoideae and the expansion of Pooideae subfamilies. The two $\mathrm{C}_{3}$-Arundinoideae species (traditional naming) in our study actually belong to the GPWG Danthonioideae subfamily and one $\mathrm{C}_{3}$-Bambusoideae species (traditional naming) belongs to the GPWG Ehrhartoideae subfamily (as displayed in Fig. 3). We do not have precise vegetation surveys from Mount Rungwe and the Masoko lake catchment area.

\section{Results}

\subsection{Phytolith assemblages, phytolith indices and vegetation zones}

Phytolith assemblages from low elevation (Lake Masoko) were clearly differentiated from those collected above $1950 \mathrm{~m}$ a.s.l. (Fig. 4 and percentages in Table 1). They presented a high abundance of Globular granulate, Globular psilate, Acicular hair cell, Cuneiform and Parallelepiped bulliform cell phytoliths, as well as a low Ic (from 0 to $8.1 \%$ ), a low Iph (0 to $11 \%$ ), and a high $D / P^{\circ}(0.5$ to 2.5$)$. We noticed that samples collected under the semi-deciduous forest and dominated by Brachystegia and Isoberlinia (MAS 7, 8 and 14 ) had lower $\mathrm{D} / \mathrm{P}^{\circ}$ values ( 0.5 to 1.3 ) than those collected under the semi-deciduous forest dominated by Uapacca (MAS 1, 3, and 9) (1.9 to 2.5). These phytolith assemblages agreed with the physiognomy of the semi-deciduous forest, which was rich in Panicoideae grasses and ligneous dicotyledons.

Phytolith assemblages from the Mountain forests $(\sim 1950$ $2300 \mathrm{~m}$ a.s.l.) on Mount Rungwe and Mount Kenya, were characterized by a medium Ic (from 33 to $53 \%$ ), a variable Iph (8 to $30 \%$ ), and a low $D / P^{\circ}(0$ to 0.17$)$. Although the Iph and Ic 
(a)

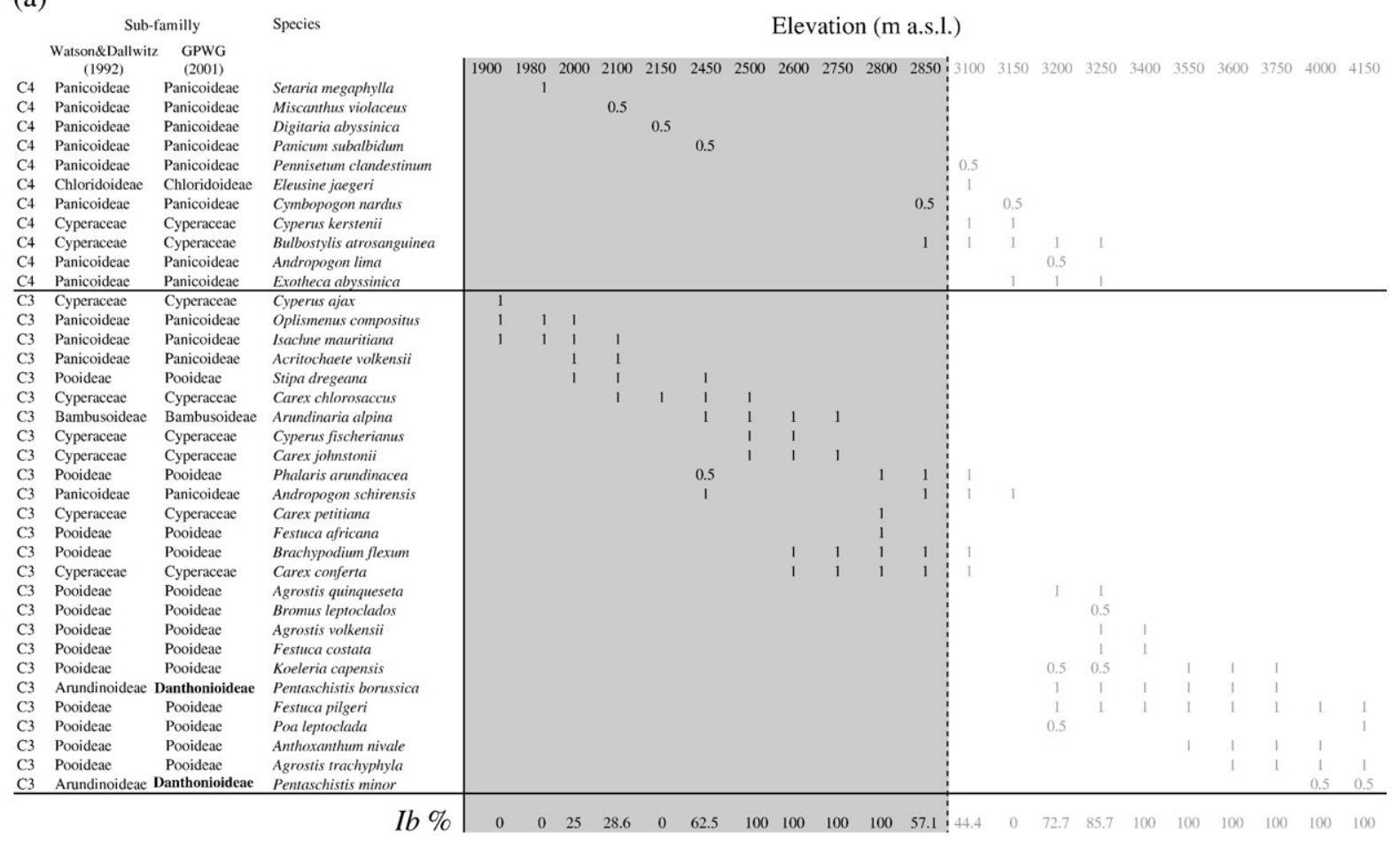

(b)

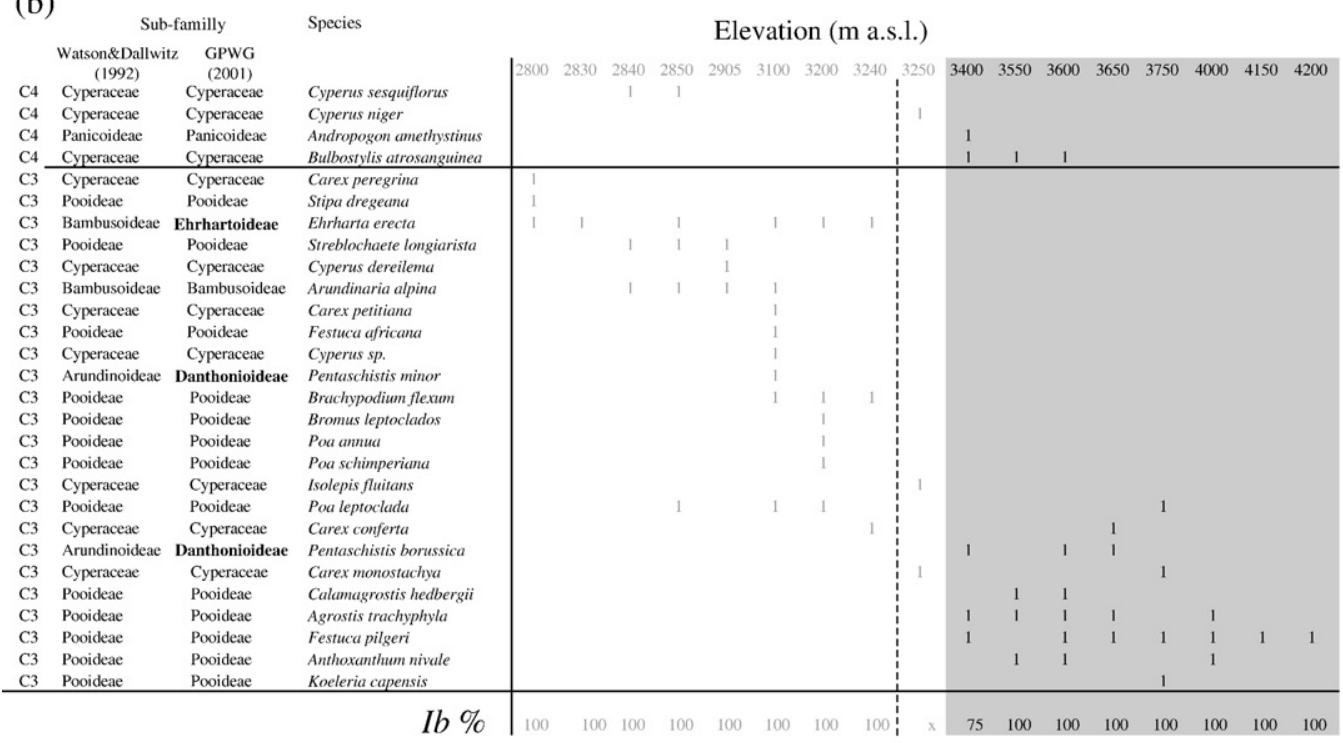

$0.5=$ not located within a quadrat but present in the locality; $1=$ located in at least one quadrat in a set of three;

0 (blank) $=$ absent from the quadrat.

-.- treeline $\quad$ Sampled for phytolith analysis

Fig. 3. Altitudinal distribution of $\mathrm{C}_{3}$ and $\mathrm{C}_{4}$ grass and sedge species on the Chogoria track (a) and Sirimon (b) tracks on Mount Kenya (modified from Wooller et al., 2001). Botanical index:

$$
\mathrm{Ib}(\%)=\frac{\text { Pooideae }+ \text { Arundinoideae }+ \text { Bambusoideae }}{\text { Pooideae }+ \text { Arundinoideae }+ \text { Panicoideae }+ \text { Chloridoideae }+ \text { Bambusoideae }} \times 100
$$

values agreed with the botanical survey described earlier (with dominant Panicoideae grasses), the $D / P^{\circ}$ was found to be very low for forested areas.
Phytolith assemblages from the Bamboo zone $(\sim 2450$ $2900 \mathrm{~m}$ a.s.1.) sampled on Mount Kenya were characterized by a greater abundance of Cuneiform and Parallepiped bulliform 


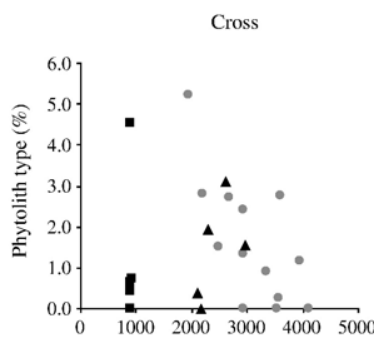

Trapeziform polylobate short cell

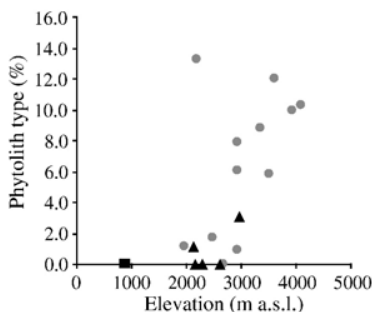

Elongate

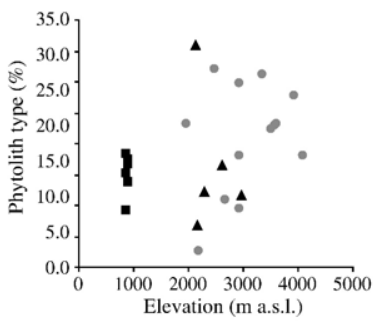

Globular psilate

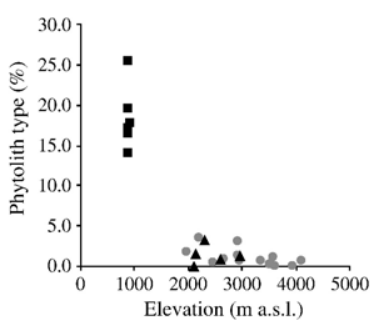

Elevation ( $m$ a.s.l.)

Samples from:

- Masoko lake

$\Delta$ Mount Rungwe
Ic \%

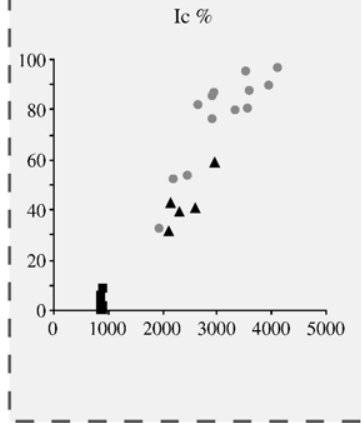

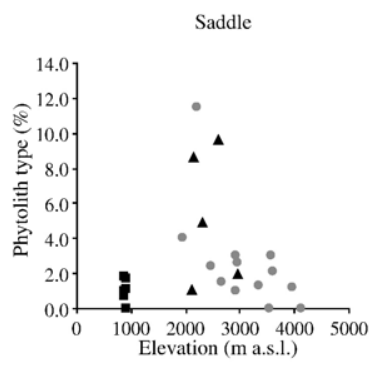
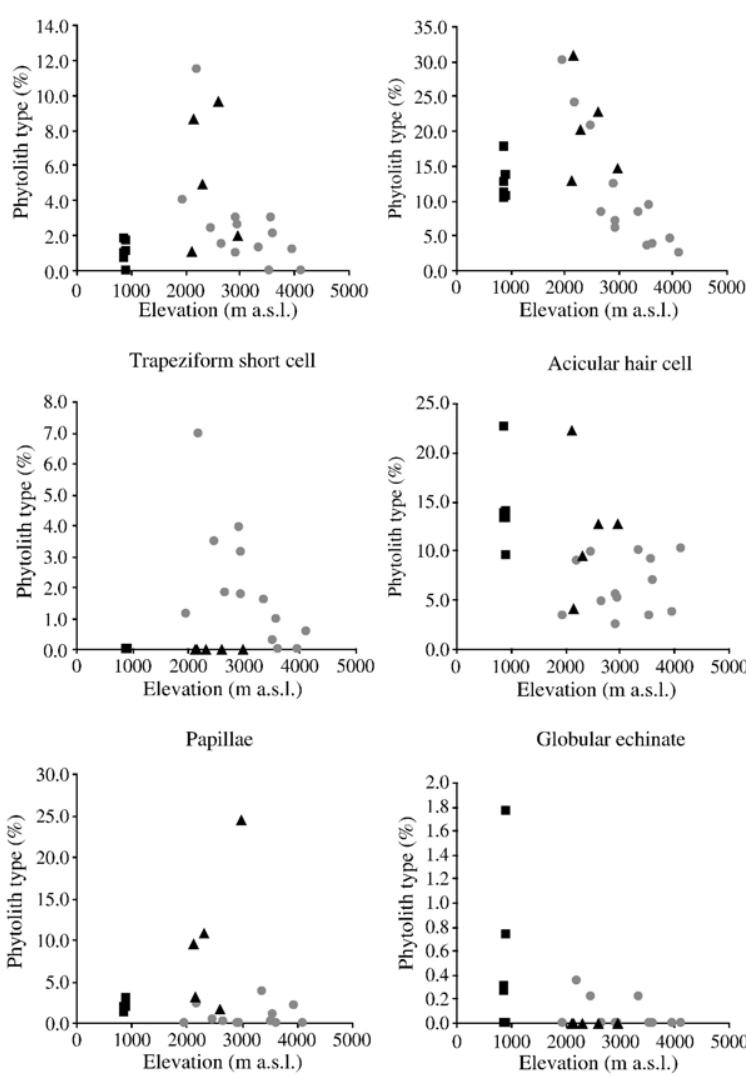

Bilobate short cell

Acicular hair cell

Globular echinate

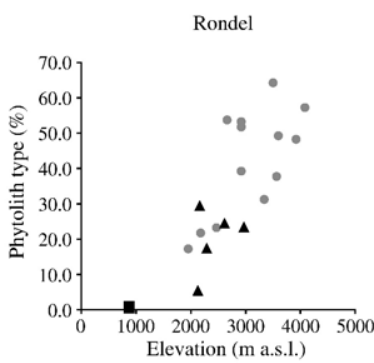

Cuneiform and paralellepiped bulliform cells

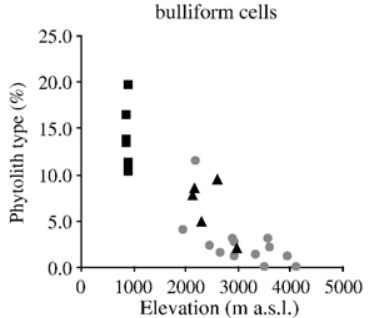

Elevation (m a.s.l.)

Globular granulate
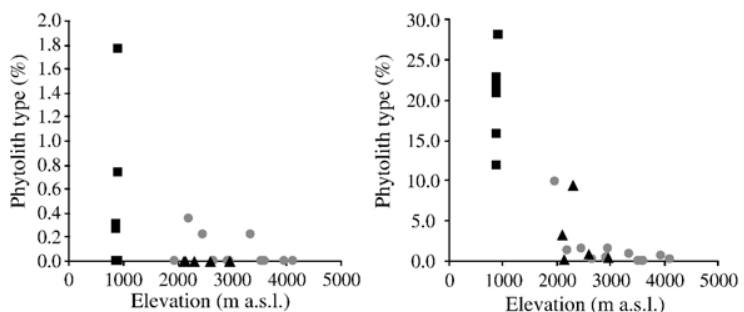

Iph \%

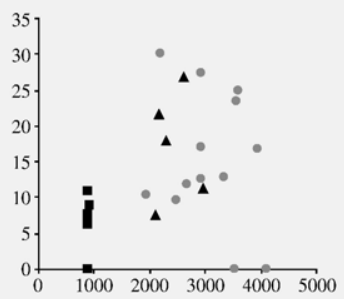

Phytolith indices
$\mathrm{D} / \mathrm{P}^{\circ}$

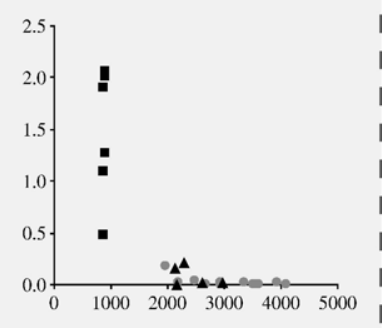

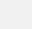

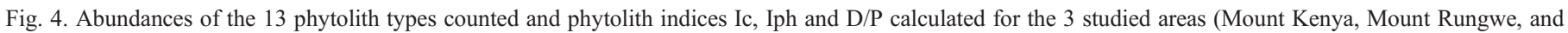

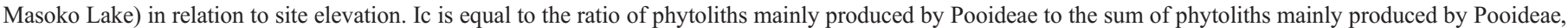
Chloridoideae and Panicoideae.

$$
\mathrm{Ic}(\%)=\frac{\text { Rondel }+ \text { Trapeziform polylobate }+ \text { Trapeziform short cell }}{\text { Rondel }+ \text { Trapeziform polylobate short cell }+ \text { Trapeziform short cell }+ \text { Saddle }+ \text { Cross }+ \text { Bilobate short cell }} \times 100
$$

Iph is the percentage of Chloridoideae short cell phytolith types relatively to the sum of Panicoideae and Chloridoideae short cell phytolith types.

$$
\operatorname{Iph}(\%)=\frac{\text { Saddle }}{\text { Saddle }+ \text { Cross }+ \text { Bilobate short cell }} \times 100
$$

$D / P^{\circ}$ index is the ratio of phytolith diagnostic of tropical woody dicotyledon, versus short cell phytoliths diagnostic of grasses.

$$
D / P^{\circ}=\frac{\text { Globular granulate }}{\text { Bilobate short cell }+ \text { Cross }+ \text { Saddle }+ \text { Rondel }+ \text { Trapeziform polylobate short cell }+ \text { Trapeziform short cell }}
$$


Table 1

Detailed counts of phytolith types (in \%), recovered from modern soil samples from the 3 studied sites in East Africa (Tanzania and Kenya)

\begin{tabular}{|c|c|c|c|c|c|c|c|c|c|c|c|c|c|c|c|c|c|c|c|c|}
\hline & $\begin{array}{l}\text { Vegetation } \\
\text { zones }\end{array}$ & Samples & $\begin{array}{l}\text { Elevation } \\
\text { (m.a.s.l.) }\end{array}$ & Cross & $\begin{array}{l}\text { Bilobate } \\
\text { short cell }\end{array}$ & Saddle & Rondel & $\begin{array}{l}\text { Trapeziform } \\
\text { polylobate } \\
\text { short cell }\end{array}$ & $\begin{array}{l}\text { Trapeziform } \\
\text { short cell }\end{array}$ & $\begin{array}{l}\text { Acicular } \\
\text { hair cell }\end{array}$ & $\begin{array}{l}\text { Cuneiform and } \\
\text { parallelepiped } \\
\text { bulliform cells }\end{array}$ & Elongate & Papillae & $\begin{array}{l}\text { Globular } \\
\text { echinate }\end{array}$ & $\begin{array}{l}\text { Globular } \\
\text { granulate }\end{array}$ & $\begin{array}{l}\text { Globular } \\
\text { psilate }\end{array}$ & $\begin{array}{l}\text { Sum (classified } \\
\text { phytoliths) }\end{array}$ & ${ }^{\mathrm{a}} \mathrm{Ic}$ & ${ }^{b} \mathrm{D} / \mathrm{P}$ & Iph \\
\hline \multirow{13}{*}{$\begin{array}{l}\text { Mt. Kenya } \\
\left(0^{\circ} \mathrm{S} ; 37.1^{\circ} \mathrm{E}\right)\end{array}$} & \multirow[t]{4}{*}{ Afroalpine zone } & UAS $1-1$ & 4111 & 0.0 & 2.5 & 0.0 & 57.0 & 10.3 & 0.6 & 10.3 & 0.6 & 17.9 & 0.0 & 0.0 & 0.3 & 0.6 & 358 & 96.43 & 0.00 & 0.00 \\
\hline & & UAS $3-3$ & 3951 & 1.2 & 4.7 & 1.2 & 48.2 & 9.9 & 0.0 & 3.8 & 0.6 & 27.8 & 2.0 & 0.0 & 0.6 & 0.0 & 342 & 89.24 & 0.01 & 16.67 \\
\hline & & LAS 2-1 & 3614 & 2.8 & 3.7 & 2.1 & 49.1 & 12.0 & 0.0 & 7.1 & 0.3 & 23.0 & 0.0 & 0.0 & 0.0 & 0.0 & 326 & 87.67 & 0.00 & 25.00 \\
\hline & & LAS 3-2 & 3570 & 0.2 & 9.5 & 3.0 & 37.7 & 13.5 & 1.0 & 9.2 & 1.0 & 22.9 & 1.0 & 0.0 & 0.0 & 1.0 & 401 & 80.38 & 0.00 & 23.53 \\
\hline & \multirow{2}{*}{$\begin{array}{l}\text { Ericaceous } \\
\text { zone }\end{array}$} & ES $1-2$ & 3527 & 0.0 & 3.5 & 0.0 & 63.9 & 5.8 & 0.3 & 3.5 & 0.3 & 22.3 & 0.3 & 0.0 & 0.0 & 0.3 & 346 & 95.28 & 0.00 & 0.00 \\
\hline & & ES 2-3 & 3353 & 0.9 & 8.3 & 1.3 & 31.2 & 8.8 & 1.6 & 10.1 & 1.1 & 31.0 & 3.8 & 0.2 & 0.9 & 0.7 & 445 & 79.74 & 0.02 & 12.77 \\
\hline & \multirow{2}{*}{$\begin{array}{l}\text { Hagenia- } \\
\text { Hypericum }\end{array}$} & H 3-1 & 2945 & 0.0 & 7.1 & 2.6 & 51.5 & 7.9 & 1.8 & 5.3 & 3.8 & 17.9 & 0.0 & 0.0 & 1.5 & 0.6 & 340 & 86.31 & 0.02 & 27.27 \\
\hline & & H 1-2 & 2928 & 1.3 & 6.1 & 1.1 & 39.1 & 6.1 & 3.2 & 5.5 & 6.1 & 29.8 & 0.0 & 0.0 & 0.5 & 1.3 & 379 & 85.12 & 0.01 & 12.50 \\
\hline & \multirow[t]{2}{*}{ Bamboo zone } & B 1-2 & 2920 & 2.4 & 12.5 & 3.0 & 52.9 & 0.9 & 4.0 & 2.4 & 9.1 & 9.4 & 0.0 & 0.0 & 0.3 & 3.0 & 329 & 76.31 & 0.00 & 16.95 \\
\hline & & В 2-3 & 2670 & 2.7 & 8.4 & 1.5 & 53.5 & 0.0 & 1.8 & 4.8 & 15.0 & 10.8 & 0.3 & 0.0 & 0.3 & 0.9 & 333 & 81.42 & 0.00 & 11.90 \\
\hline & \multirow{3}{*}{$\begin{array}{l}\text { Mountain } \\
\text { forest }\end{array}$} & UM 1-2 & 2477 & 1.5 & 20.8 & 2.4 & 22.9 & 1.7 & 3.5 & 10.0 & 2.6 & 32.0 & 0.4 & 0.2 & 1.5 & 0.4 & 462 & 53.28 & 0.03 & 9.65 \\
\hline & & UM 3-1 & 2193 & 2.8 & 24.0 & 11.5 & 21.3 & 13.2 & 7.0 & 9.1 & 1.0 & 2.4 & 2.4 & 0.3 & 1.4 & 3.5 & 287 & 51.97 & 0.02 & 30.00 \\
\hline & & LM 1-2 & 1958 & 5.2 & 30.2 & 4.1 & 16.9 & 1.2 & 1.2 & 3.5 & 2.9 & 23.3 & 0.0 & 0.0 & 9.9 & 1.7 & 172 & 32.67 & 0.17 & 10.29 \\
\hline \multirow{7}{*}{$\begin{array}{l}\text { Mt. Rungwe } \\
\left(9^{\circ} \mathrm{S}, 33^{\circ} \mathrm{E}\right)\end{array}$} & \multirow[t]{3}{*}{ Afroalpine zone } & RGW 27 & 2966 & 1.5 & 14.7 & 2.1 & 23.4 & 3.1 & 0.0 & 12.9 & 4.4 & 11.8 & 24.4 & 0.0 & 0.5 & 1.3 & 389 & 59.20 & 0.01 & 11.27 \\
\hline & & RGW 24 & 2600 & 3.1 & 22.9 & 9.6 & 24.4 & 0.0 & 0.0 & 12.7 & 7.1 & 16.7 & 1.7 & 0.0 & 0.8 & 0.8 & 353 & 40.57 & 0.01 & 26.98 \\
\hline & & RGW 23 & 2300 & 2.0 & 20.3 & 4.9 & 17.6 & 0.0 & 0.0 & 9.5 & 9.8 & 12.4 & 10.8 & 0.0 & 9.5 & 3.3 & 306 & 39.42 & 0.21 & 18.07 \\
\hline & \multirow{2}{*}{$\begin{array}{l}\text { Mountain } \\
\text { forest }\end{array}$} & RGW 19 & 2150 & 0.0 & 31.0 & 8.7 & 29.6 & 0.0 & 0.0 & 4.2 & 14.6 & 6.9 & 3.3 & 0.0 & 0.3 & 1.5 & 335 & 42.67 & 0.00 & 21.80 \\
\hline & & RGW 2 & 2113 & 0.4 & 13.0 & 1.1 & 5.6 & 1.1 & 0.0 & 22.2 & 7.8 & 35.9 & 9.6 & 0.0 & 3.3 & 0.0 & 270 & 31.58 & 0.16 & 7.69 \\
\hline & \multirow{6}{*}{$\begin{array}{l}\text { Semi- } \\
\text { deciduous forest }\end{array}$} & MAS 1 & 898 & 0.4 & 10.4 & 0.0 & 0.0 & 0.0 & 0.0 & 9.6 & 19.6 & 16.7 & 2.1 & 0.0 & 21.7 & 19.6 & 240 & 0.00 & 2.00 & 0.00 \\
\hline & & MAS 3 & 885 & 0.0 & 11.2 & 0.7 & 0.0 & 0.0 & 0.0 & 13.8 & 13.8 & 18.3 & 2.2 & 0.0 & 22.8 & 17.2 & 268 & 0.00 & 1.91 & 6.25 \\
\hline \multirow{4}{*}{$\begin{array}{l}\text { Masoko lake } \\
\quad\left(9^{\circ} 2^{\prime} \mathrm{S}, 33^{\circ} 45^{\prime} \text { E) }\right.\end{array}$} & & MAS 7 & 901 & 0.7 & 13.7 & 1.8 & 0.2 & 0.0 & 0.0 & 14.1 & 11.2 & 17.4 & 2.0 & 1.8 & 20.7 & 16.5 & 454 & 1.35 & 1.27 & 10.96 \\
\hline & & MAS 8 & 881 & 0.0 & 12.7 & 1.0 & 0.8 & 0.0 & 0.0 & 22.6 & 16.4 & 15.1 & 1.3 & 0.3 & 15.8 & 14.0 & 385 & 5.36 & 1.09 & 7.55 \\
\hline & & MAS 9 & 909 & 0.7 & 10.7 & 1.1 & 1.1 & 0.0 & 0.0 & 13.2 & 10.3 & 13.6 & 2.9 & 0.7 & 27.9 & 17.6 & 272 & 8.11 & 2.05 & 8.82 \\
\hline & & MAS 14 & 878 & 4.5 & 17.9 & 1.8 & 0.6 & 0.0 & 0.0 & 13.3 & 13.3 & 9.1 & 1.8 & 0.3 & 11.8 & 25.5 & 330 & 2.44 & 0.48 & 7.50 \\
\hline
\end{tabular}

$\overline{\mathrm{a}} \mathrm{Ic}=$ Pooideae phytoliths (Rondel+ Trapeziform polylobate short cell + Trapeziform short cell) Vs. Pooideae phytoliths (Rondel + Trapeziform polylobate short cell + Trapeziform short cell) + Panicoideae phytoliths $($ Saddle + Cross + Bilobate short cell).

${ }^{6} \mathrm{D} / \mathrm{P}^{\circ}=$ Ligneous dicotyledon phytoliths (Globular granulate type) $/$ Poaceae phytoliths (Bilobate short cell + Cross + Saddle + Rondel + Trapeziform polylobate short cell + Trapeziform short cell).

${ }^{\mathfrak{C}}$ Iph=Chloridoideae phytoliths (Saddle type) Vs. Chloridoideae and Panicoideae phytoliths (Saddle+Cross +Bilobate short cell types) 

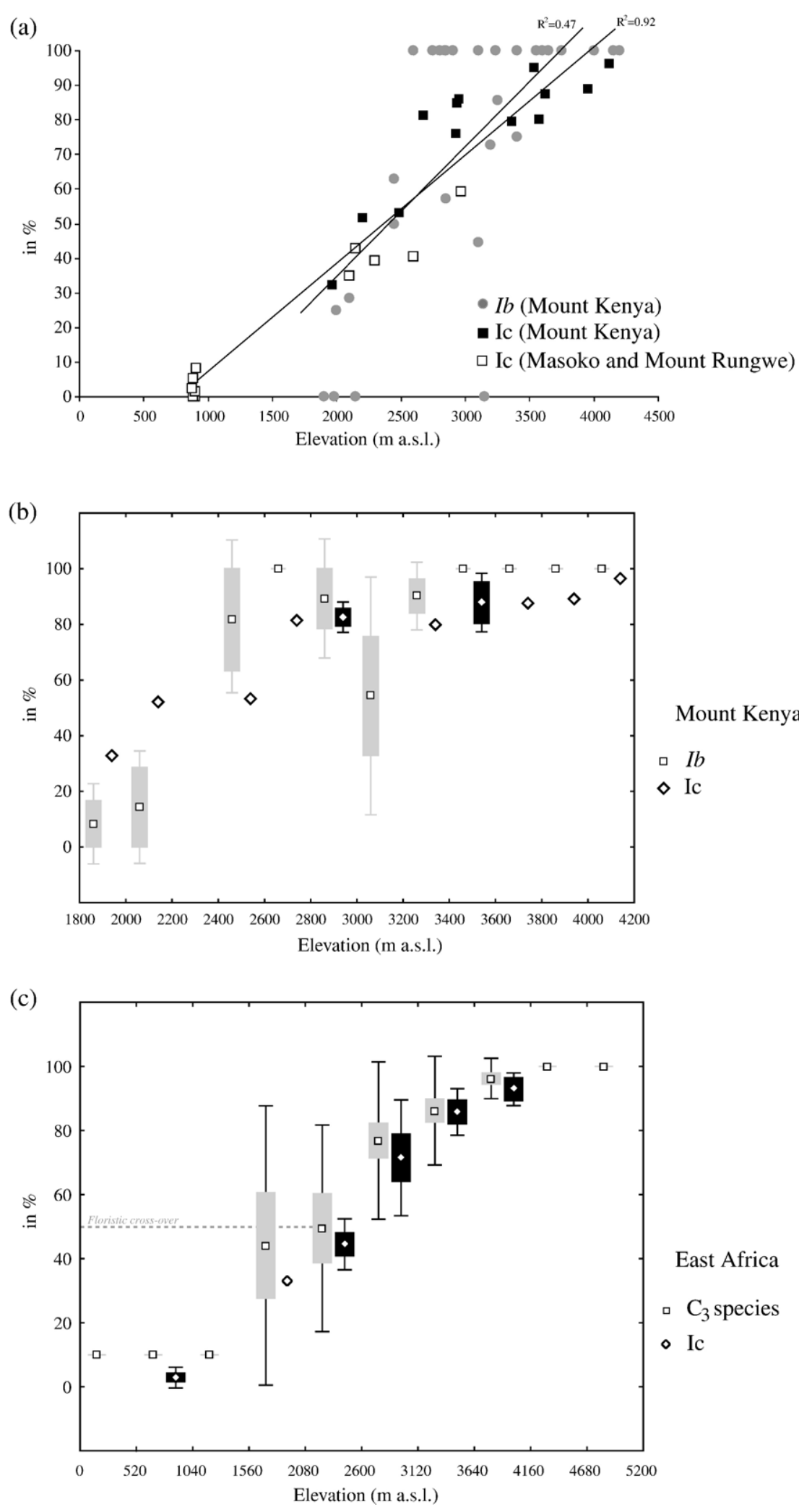

Fig. 5. Characteristics of Ic and Ib indices: a) Increase of the Ic (calculated for samples from Masoko lake, Mount Rungwe and Mount Kenya) and Ib indices (calculated with Mount Kenya botanical statements) with elevation. Slope coefficients are 0.0302 for Ic and 0.0376 for Ib, and determination coefficients $R^{2}$ are 0.92 for Ic and 0.47 for Ib, respectively. b) Phytolith and botanical indices (Ic and Ib) calculated for Mount Kenya are reported using 12 box plots with equal interval (200 m) from 1800 to $4200 \mathrm{~m}$ a.s.1. (mid-point: mean values of the selected variable; the box: \pm standard errors $(S-E)$; and whiskers: $+/-$ standard deviation $(S-D)$ ). c) Ic values calculated for all the samples (Masoko lake, Mount Rungwe and Mount Kenya) are compared to available botanical data (\% of $\mathrm{C}_{3}$ grass species) published for East Africa (Tieszen et al., 1979; Livingstone and Clayton, 1980; Young and Young, 1983; Wooller et al., 2001). Data are reported using 10 box plots with equal interval from 0 to $5200 \mathrm{~m}$ a.s.1 (mid-point: mean values of the selected variable; the box: $+/-$ standard errors $(S-E)$; and whiskers: $+/-$ standard deviation $(S-D)$ ). 
cells ( $9 \%$ and $15 \%$ ) than other mountain zones. The Saddle type was present but not abundant (1.5 and 3\%), contrasting with the abundance of Bilobate short cell type that ranged from $8.4 \%$ to $12.5 \%$ and the Pooideae phytolith types that range from $52.9 \%$ to $53.5 \%$. As Chloridoideae grasses were absent from the quadrats, the recorded Saddle type could be attributed to the phytolith production of Bambusoideae grasses. A particular attention was given to identify sub-types of Saddles in the Bamboo zone. The Collapsed Saddle, Long Saddle and Short Saddle types accounted respectively for $51 \%, 92 \%$ and $8 \%$ of the saddle types and for $1.1 \%, 2.1 \%$ and $0.1 \%$ of the sum of classified phytoliths. These abundances are very low. For comparison, sub-types of Saddle from two samples (UM 3-1 and $\mathrm{H} \mathrm{3-1)}$ surrounding the bamboo zone and devoid of bamboo cover were also counted: the Collapsed Saddle, Long Saddle and Short Saddle types accounted respectively for $18.5 \%, 86 \%$ and $14 \%$ of the Saddle types and for $1.2 \%, 6.5 \%$ and $0.5 \%$ of the sum of classified phytoliths. Ic was relatively high (76 and $81 \%$ ), both in agreement with the presence of Pooideae grasses and likely with the production of "Pooideae phytolith types" by the local Bambusoideae grasses. Iph showed medium values (between $17 \%$ and $12 \%$ ) and the $\mathrm{D} / \mathrm{P}^{\circ}$ was almost zero.

Phytolith assemblages from the Hagenia-Hypericum and Ericaceous zones $(\sim 2900-3000 \mathrm{~m}$ a.s.l. and $\sim 3000$ $3400 \mathrm{~m}$ a.s.l.) were not clearly distinguished through phytolith indices. Ic was high, up to $80 \%$, in agreement with the dominance of Pooideae in the vegetation. Iph ranged from 0 to $27 \%$ although the grass cover was devoid of Chloridoideae, Bambusoideae and Panicoideae subfamilies. These subfamilies produce many of the phytolith types involved in the Iph calculation. $\mathrm{D} / \mathrm{P}^{\circ}$ was very low (0 to 0.02$)$ although shrubs were present but not trees.

Phytolith assemblages from the upper grasslands in the Afroalpine zone (from $3500 \mathrm{~m}$ a.s.l.) were characterized by the highest Ic values ( 80 to $96 \%$ ), variable Iph ( 0 to $25 \%$ ), and $\mathrm{D} / \mathrm{P}^{\circ}$ was 0.02 , in agreement with the vegetation survey (absence of trees and Pooideae grasses dominant).

\subsection{Increasing values of both phytolith index Ic and botanical index Ib with elevation}

The Ic index displayed a strong positive relationship with elevation, from $3 \%$ at $780 \mathrm{~m}$ a.s.l. to $50 \%$ at $2300 \mathrm{~m}$ a.s.l. and $90 \%$ at $4000 \mathrm{~m}$ a.s.l. Ic (Fig. 5a, calculated for Masoko, Mount Rungwe and Mount Kenya). The Ib index (available for Mount Kenya only) showed a similar but weaker trend with elevation as evidenced by the similar coefficient slopes but different significant determination coefficients.

In order to discuss our results from Mount Kenya in a regional context, we calculated Ic and $\mathrm{Ib}$ for twelve $200 \mathrm{~m}$ a.s.l. elevation zones, from 1800 to $4200 \mathrm{~m}$ a.s.l. (Fig. 5b). Box plots show a high dispersion of the botanical index Ib (standard deviation $>20 \%$ ) by contrast with the narrow standard deviation of Ic (less than 10\%) for the two boxes where at least two phytolith samples were available. When comparing averages, similar trends with elevation were displayed although three cases could be distinguished: 1) Below $2400 \mathrm{~m}$ a.s.l., in mountain forest, average Ic was $\sim 30 \%$ higher than the average $\mathrm{Ib}$; the difference being higher than the Ib standard deviation 2) From 2400 to $3400 \mathrm{~m}$ a.s.l., the average Ic was less than $\sim 20 \%$ lower than the average $\mathrm{Ib}$, the difference being close to the $\mathrm{Ib}$ standard deviation. At 3000-3200 m a.s.l., Ib decreased sharply, likely related to the presence of Panicoideae grasses $\left(\mathrm{C}_{4}\right)$ just above the tree line (Wooller et al., 2001). However, no Ic data were available for comparison. 3) Above $3400 \mathrm{~m}$ a.s.l., in Afroalpine and Nival zones, the average Ic was around $90 \%$ while the average $\mathrm{Ib}$ reached $100 \%$.

The percentage of $\mathrm{C}_{3}$ species, calculated from literature (over East-Africa) for each elevation zones on Mont Kenya, Mount Rungwe and at Masoko, showed an increase with elevation associated with a high standard deviation, evidencing regional heterogeneity (Fig. $5 \mathrm{c}$ ). Nevertheless, Ic values showed the same trend as the $\mathrm{C}_{3}$ grasses percentages. Moreover, the grass subfamily crossover point mirrored by an Ic value of $50 \%$ and the floristic $\mathrm{C}_{3} / \mathrm{C}_{4}$ grass crossover point occurred both at a similar elevation range between 2080 and $2600 \mathrm{~m}$ a.s.l.

\section{Discussion}

This study showed that the combination of three phytolith indices, namely Ic, Iph, and $\mathrm{D} / \mathrm{P}^{\circ}$, can be used to discriminate the different vegetation zones on East-African Mountains. We discuss in the following subsections each phytolith index with its advantages and limitations.

\subsection{Ic index increases with elevation and reflects vegetation changes from $C_{4}$ to $C_{3}$ grass dominance}

This study demonstrated that proportions of Pooideae, Arundinoideae and Bambusoideae ( $\mathrm{C}_{3}$-grasses) versus Panicoideae (mainly $\mathrm{C}_{4}$-grasses), increasing with elevation at Masoko, on Mount Rungwe and Mount Kenya, matched with an increase in Ic values. This was illustrated by the similar slopes of Ic and Ib on Mount Kenya (Fig. 5a). Ic was close to zero when Pooideae, Arundinoideae and Bambusoideae grasses were absent, such as in tropical low elevation areas (e.g. around Lake Masoko), and close to $50 \%$ when these three subfamilies were represented in proportions similar to Panicoideae. When the grass cover was exclusively composed of $\mathrm{C}_{3}$-Pooideae and Arundinoideae, at high elevation, the Ic reached maximum values from 80 to $96 \%$.

Local discrepancies between Ic and Ib (Fig. 5b) were expected for the four following reasons: 1) Ib was not calculated from corresponding biomass values, whereas phytolith production was directly related. 2) Redundancy and multiplicity, inherent to phytolith production, prevents associating one phytolith type to one taxon. At high elevation, where Ib reached $100 \%$, we assumed that Ic values stayed at $\sim 90 \%$ because small amounts of Saddle, Cross and Bilobate short cell phytoliths can be produced by some species of Pooideae and Arundinoideae grasses in the Afroalpine zone. 3) Ib may give a more local representation of vegetation than Ic. Indeed, Ic may integrate phytoliths transported by wind, runoff or grazing, from areas beyond a sampling quadrat. The following example 
illustrates this discrepancy. Sampling site LM 1-2 (Table 1) gave an $\mathrm{Ib}$ of 0 and an Ic of 32.7. The sampled site was covered by trees and/or bare soil and almost less than $1 \%$ of Oplismenus compositus $\left(\mathrm{C}_{3}\right.$ Panicoideae grass). However, although the phytolith assemblage showed a significant amount of Cross and Bilobate short cells types (35\%) attributed to Panicoideae, it was also characterized by $19 \%$ of the Rondel, Trapeziform polylobate short cell and Trapeziform short cell types mainly produced by Pooideae and Arundinoideae. Further analyses of the botanical survey data showed the occurrence of Stipa dregeana $\left(\mathrm{C}_{3}\right.$ Pooideae grass) noted a few meters away, which can produce Rondel, Trapeziform polylobate short cell and Trapeziform short cell types. Such external phytolith inputs may partly explain higher Ic values relative to $\mathrm{Ib}$ values at low elevations, in addition to the bias due to multiplicity and redundancy patterns. 4) Interferences with phytoliths produced by Bamboos. Mountain bamboo zones in East Africa are often dominated by the Arundinaria alpina (tribe Bambuseae), as on Mount Kenya. Our study showed that this vegetation did not produce in significant proportion the Long and Collapsed Saddle phytolith types, as expected from the literature on Bambusoideae grasses (mainly subtribes Guaduineae and Chusqueinae) from other areas. Instead, the bamboo zone dominated by Arundinaria alpina produce a relatively high proportion of the "Pooideae phytolith types" and the Bilobate short cell type in relatively low proportions. This subsequently made the phytolith Ic value lower than the Ic from the Pooideae grassland of the Afroalpine zone.

Grass phytolith data are often used as an indicator of $\mathrm{C}_{3}$ versus $\mathrm{C}_{4}$ grasses. This study highlighted the need to be more accurate when interpreting such data: the Ic index is a proxy of grass subfamily dominance, often, but not always, indicative of $\mathrm{C}_{3}$ versus $\mathrm{C}_{4}$ grass dominance. In tropical mountain areas, grasses growing in the shade of a mountain forest canopy can use a $\mathrm{C}_{3}$ although they belong to the Panicoideae subfamily (Tieszen et al., 1979) that is composed of $78 \% \mathrm{C}_{4}$ grasses, and producing phytolith types sometimes wrongly interpreted as " $\mathrm{C}_{4}$ phytoliths". In this case, the phytolith index Ic is indicative of the dominant subfamily only. However, in open areas such as grasslands, shrublands and open forests, Panicoideae grasses are often $\mathrm{C}_{4}$ and the Ic index can be reasonably interpreted as a proxy of $\mathrm{C}_{3}$ versus $\mathrm{C}_{4}$ grass abundance. An increase in the abundance of Pooideae grasses at the expense of Panicoideae grasses with elevation, have been observed along altitudinal gradients, all over the inter-tropical world (Costa Rica, Hawaï, East-Africa, Argentina) (Chazdon, 1978; Tieszen et al., 1979; Livingstone and Clayton, 1980; Young and Young, 1983; Cabido et al., 1997). These studies investigated open formations where Panicoideae grasses were all $\mathrm{C}_{4}$. The floristic crossover point between $\mathrm{C}_{4}$ and $\mathrm{C}_{3}$ species was identified at different elevations (1000 to $3000 \mathrm{~m}$ a.s.l), due to different climate features or perturbations. Better knowledge of current location of the crossover point between $\mathrm{C}_{4}$ and $\mathrm{C}_{3}$ grasses is necessary to understand environmental parameters constraining the competitive basis of $\mathrm{C}_{3} / \mathrm{C}_{4}$ grass interactions, to predict $\mathrm{C}_{3} / \mathrm{C}_{4}$ grass distributions, and inversely, to reconstruct climate parameters from fossil records of $\mathrm{C}_{3} / \mathrm{C}_{4}$ grass distributions.
4.2. Iph index as a proxy of $C_{4}$ short-versus $C_{4}$ tall-grasses at low elevation

Our set of phytolith assemblages presents Iph indices ranging from 0 to $27 \%$, although Chloridoideae grasses are nearly absent from the studied grass covers. Indeed, except for one quadrat at $3100 \mathrm{~m}$ a.s.l. on Mount Kenya (no related phytolith sample), where a Chloridoideae grass species (Eleusine jaegeri) has been observed (Wooller et al., 2001), this subfamily is not present. Although produced in abundance by Chloridoideae, the Saddle phytolith type may also be produced by Arundinoideae and Bambusoideae, and to a lesser extent by Pooideae as aforementioned. Thus, when these $\mathrm{C}_{3}$-subfamilies are well represented, which is the case in this study, Iph is not a relevant proxy of Chloridoideae $\left(\mathrm{C}_{4}\right.$-short grasses $)$ versus Panicoideae $\left(\mathrm{C}_{4}\right.$-tall grasses) as demonstrated for West Africa (Bremond et al., 2005b).

\subsection{The $D / P^{\circ}$ index as proxy of tree cover density at low elevation}

We show that the semi-deciduous forest woodland surrounding the Lake Masoko at $800-900 \mathrm{~m}$ a.s.l. recorded a $D / P^{\circ}$ ranging from 0.5 to 2.1 . The 2.1 value is consistent with the actual tree cover density, but slightly lower than the $D / P^{\circ}$ measured in another semi-deciduous forest in Central Africa with an equivalent Leaf Area Index of 2 (recalculated from Bremond et al., 2005a). We think that the $0.5 \mathrm{D} / P^{\circ}$ value observed under the Brachystegia-Isoberlinia semi-deciduous forest in a Masoko sample underestimates the tree cover density because similar values commonly trace grass savannas (Alexandre et al., 1999; Bremond et al., 2005b). Such a difference may be explained by the low Globular granulate phytolith productivity of one species relative to another.

We show that at higher elevation, the tree cover density of the mountain forest is clearly not mirrored by the $D / P^{\circ}$ that is close or equal to zero. This suggests that woody dicotyledons dominating the mountain forest on Mount Kenya and Mount Rungwe (e.g. Macaranga, Cassipourea, Tabernaeomontana, Canthium, Vitex, Hagenia, Hypericum and Erica arborea) do not produce, in the studied environmental conditions, the Globular granulate phytolith type used for calculating $D / P^{\circ}$. This result restricts the geographical application of the $D / P^{\circ}$ phytolith index to low elevation inter-tropical areas. In other terms, this phytolith index should be optimally useful for vegetation reconstructions if warm and low elevation conditions are assumed through complementary study. In agreement with this conclusion, Barboni et al. (2007) showed that $D / P^{\circ}$ values, recalculated from published data from inter-tropical African sites of low elevation, fit well with Leaf Area Index values estimated from satellite data.

\section{Conclusion}

For the first time, soil phytolith assemblages were compared with vegetation surveys over a tropical elevation range. This study pointed out several methodological points, to be considered when using phytoliths as a proxy of vegetation 
and especially of grass subfamily dominance and $\mathrm{C}_{3} / \mathrm{C}_{4}$ grass distribution:

1) The Phytolith index $D / P^{\circ}$ is not a relevant indicator of tree cover density in tropical mountain forests. We assumed that the Globular granulate type is not systematically produced by the ligneous dicotyledon taxa characteristic of the Afromontane vegetation (i.e. Macaranga, Cassipourea, Tabernaeomontana, Canthium, Vitex, Hagenia, hypericum and Erica arborea).

2) The Phytolith index Iph is not a relevant indicator of Chloridoideae $\left(\mathrm{C}_{4}\right.$-short grasses $)$ versus Panicoideae $\left(\mathrm{C}_{4}\right.$-tall grasses) when $\mathrm{C}_{3}$-Pooideae and Arundinoideae grasses are present, which may be the case in tropical mountain areas.

3) The Phytolith index Ic is a promising quantitative proxy of the proportions of Pooideae, Arundinoideae and Bambusoideae grasses $\left(\mathrm{C}_{3}\right.$-grasses) versus Panicoideae grasses, which increases with elevation. An Ic value of $50 \%$ indicates the floristic subfamily cross-over point.

4) When tropical mountains are covered by open habitats (e.g. grasslands, shrublands and open forests), Ic should be a reliable proxy of $\mathrm{C}_{3} / \mathrm{C}_{4}$ grass distribution.

These results obtained from modern phytolith assemblages highlight the value of the phytolith index Ic for interpreting paleo-environmental records. Using the Ic index would provide a better understanding of past local and regional $\mathrm{C}_{3} / \mathrm{C}_{4}$ grass distribution and associated climatic changes and increases the set of $\mathrm{C}_{3} / \mathrm{C}_{4}$ data available for model/data comparisons.

\section{Acknowledgements}

Special thanks to A. Issah, M, Jenk, E. Mwandapile (Masoko village) and S. Kajula (University of Dar es Salaam) for their help during field work in Tanzania. We thank Y. Garcin for the topography data of Masoko lake catchments. This work was supported by the French projects ECHO and "Calibration des indices phytolithiques pour l'intégration de la dynamique des biomes herbacés dans la modélisation des végétations passées") of the PNEDC-INSU program and "Climate-EnvironmentHuman Interactions in Africa"(CLEHA) of the ECLIPSE-INSU program (CNRS, France), ACI "Ecologie Quantitative" (RESOLVE project), by the Tanzanian Commission for Science and Technology (COSTECH), and by the 5th EU PCRDT (EVK2CT-2002-00153: MOTIF). We thank two anonymous reviewers for their constructive suggestions, which subsequently improved our paper.

\section{References}

Abrantes, F., 2003. A 340,000 year continental climate record from tropical Africa - news from opal phytoliths from the equatorial Atlantic. Earth and Planetary Science Letters 209 (1-2), 165-179.

Albert, R.M., Bamford, M.K., Cabanes, D., 2006. Taphonomy of phytoliths and macroplants in different soils from Olduvai Gorge (Tanzania) and the application to Plio-Pleistocene palaeoanthropological samples. Quaternary International 148 (1), 78-94.

Alexandre, A., Meunier, J.-D., Lézine, A.-M., Vincens, A., Schwartz, D., 1997. Phytoliths indicators of grasslands dynamics during the late Holocene in intertropical Africa. Palaeogeography, Palaeoclimatology, Palaeoecology 136, 213-219.

Alexandre, A., Meunier, J.-D., Mariotti, A., Soubies, F., 1999. Late Holocene phytolith and carbon-isotope record from a latosol at Salitre, South-Central Brazil. Quaternary Research 51, 187-194.

Baker, R.G., Fredlund, G.G., Mandel, R.D., Bettis, E.A., 2000. Holocene environments of the central Great Plains: multi-proxy evidence from alluvial sequences, southeastern Nebraska. Quaternary International 67, 75-88.

Barboni, D., Bremond, L., Bonnefille, R., 2007. Comparative study of modern phytolith assemblages from inter-tropical Africa. Palaeogeography Palaeoclimatology Palaeoecology 246, 454-470.

Beuning, K.R.M., Scott, J.E., 2002. Effects of charring on the carbon isotopic composition of grass (Poaceae) epidermis. Palaeogeography, Palaeoclimatology, Palaeoecology 177 (1-2), 169-181.

Blinnikov, M., Busacca, A., Whitlock, C., 2002. Reconstruction of the late Pleistocene grassland of the Columbia basin, Washington, USA, based on phytolith records in loess. Palaeogeography, Palaeoclimatology, Palaeoecology $177,77-101$

Boom, A., Marchant, R., Hooghiemstra, H., Sinninghe Damsté, J.S., 2002. $\mathrm{CO} 2$ - and temperature-controlled altitudinal shifts of $\mathrm{C} 4$ - and $\mathrm{C} 3$-dominated grasslands allow reconstruction of palaeoatmospheric pCO2. Palaeogeography, Palaeoclimatology, Palaeoecology 177 (1-2), 151-168.

Bremond, L., Alexandre, A., Vela, E., Guiot, J., 2004. Advantages and disadvantages of phytolith analysis for the reconstruction of Mediterranean vegetation: an assessment based on modern phytolith, pollen and botanical data (Luberon, France). Review of Palaeobotany and Palynology 129 (4), 213-228.

Bremond, L., Alexandre, A., Hély, C., Guiot, J., 2005a. A phytolith index as a proxy of tree cover density in tropical areas: calibration with Leaf Area Index along a forest-savanna transect in southeastern Cameroon. Global and Planetary Change 45 (4), 277-293.

Bremond, L., Alexandre, A., Peyron, O., Guiot, J., 2005b. Grass water stress estimated from phytoliths in West Africa. Journal of Biogeography 32 (2), 311-327.

Brown, D.A., 1984. Prospect and limits of a phytolith key for grasses in central United States. Journal of Archaeological Science 11, 345-368.

Cabido, M., Ateca, N., Astegiano, M.E., Anton, A.M., IMBIV, U.-C., 1997. Distribution of $\mathrm{C} 3$ and $\mathrm{C} 4$ grasses along an altitudinal gradient in Central Argentina. Journal of Biogeography 24, 197-204.

Carter, J.A., 2002. Phytolith analysis and paleoenvironmental reconstruction from Lake Poukawa Core, Hawkes Bay, New Zealand. Global and Planetary Change 33, 257-267.

Cerling, T.E., Harris, J.M., MacFadden, B.J., Leakey, M.G., Quade, J., Eisenmann, V., Ehleringer, J.R., 1997. Global vegetation change through the Miocene/Pliocene boundary. Nature 389, 153-158.

Chazdon, R.L., 1978. Ecological aspects of the distribution of C4 grasses in selected habitats of Costa Rica. Biotropica 10 (4), 265-269.

Collatz, G.J., Berry, J.A., Clark, J.S., 1998. Effects of climate and atmospheric $\mathrm{CO} 2$ partial pressure on the global distribution of $\mathrm{C} 4$ grasses: present, past, and future. Oecologia 114, 441-454.

Delhon, C., Alexandre, A., Berger, J.-F., Thiébault, S., Brochier, J.-L., Meunier, J.-D., 2003. Phytolith assemblages as a promising tool for reconstructing Mediterranean Holocene vegetation. Quaternary Research 59 (1), 48-60.

Descolas-Gros, C., Calleja, M., Cour, P., Richard, P., Perruchietti, C., Jame, P., 2001. Carbon isotopic ratios of pollen: interest for palaeovegetations reconstructions. Comptes Rendus De l'Academie des Sciences 332 (12), 755-760.

Diester-Haass, L., Schrader, H.J., Thiede, J., 1973. Sedimentological and paleoclimatological investigations of two pelagic ooze cores off Cape Barbas, North-West Africa. Meteor Forshungergebnisse 16, 19-66.

Ehleringer, J.R., Cerling, T.E., Helliker, B.R., 1997. C4 photosynthesis, atmospheric CO2, and climate. Oecologia 112, 285-299.

F.A.O., 1998. World reference base for soil resources. FOOD AND AGRICULTURE ORGANIZATION OF THE UNITED NATIONS, Rome.

Ficken, K.J., Wooller, M.J., Swain, D.L., Street-Perrott, F.A., Eglinton, G., 2002. Reconstruction of a subalpine grass-dominated ecosystem, Lake Rutundu, Mount Kenya: a novel multi-proxy approach. Palaeogeography, Palaeoclimatology, Palaeoecology 177 (1-2), 137-149.

Fredlund, G., 1993. Paleoenvironmental interpretations of stable carbon, hydrogen, and oxygen isotopes from opal phytoliths, Eustis Ash Pit, Nebraska. In: 
Pearsall, D., Piperno, D. (Eds.), Current Research in Phytolith Analysis: Applications in Archaeology and Paleoecology. MASCA Research Papers in Science and Archaeology, University of Pennsylvania Museum, pp. 46-69.

Fredlund, G., Tieszen, L.T., 1994. Modern phytolith assemblages from the North American Great Plains. Journal of Biogeography 21 (3), 321-335.

Fredlund, G., Tieszen, L.T., 1997. Calibrating grass phytoliths assemblages in climatic terms: Application to the late Pleistocene assemblages from Kansas and Nebraska. Palaeogeography, Palaeoclimatology, Palaeoecology 136, 199-211.

Garcin, Y., Williamson, D., Taieb, M., Vincens, A., Mathe, P.-E., Majule, A., 2006. Centennial to millennial changes in maar-lake deposition during the last 45,000 years in tropical Southern Africa (Lake Masoko, Tanzania). Palaeogeography, Palaeoclimatology, Palaeoecology 239 (3-4), 334-354.

GPWG, 2001. Phylogeny and subfamilial classification of the grasses (Poaceae). Annals of the Missouri Botanical Garden 88, 373-457.

Harkin, D.A., 1959. The Rungwe volcanics at the northern end of Lake Nyasa. Geological Survey of Tanzania, Dodoma. 224 pp.

Haxeltine, A., Prentice, I.C., 1996. BIOME3: an equilibrium terrestrial biosphere model based on ecophysiological constraints, resource availability, and competition among plant functional type. Global Biogeochemical Cycles 10, 693-709.

Kaplan, L., Smith, M.B., Sneddon, L.A., 1992. Cereal grain phytoliths of Southwest Asia and Europe. In: Rapp, G.J., Mulholland, S.C. (Eds.), Phytoliths systematics, Emerging issues. Advances in archaeological and museum science, New York, pp. 149-174.

Kelly, E.F., 1990. Method for extracting opal phytoliths from soil and plant material. Intern. Rep., Dep. Agron. Colorado State Univ., Fort Collins.

Kelly, E.F., Amundson, R.G., Marino, B.D., Deniro, M.J., 1991. Stable isotope ratios of carbon in phytoliths as a quantitative method of monitoring vegetation and climate change. Quaternary Research 35, 222-233.

Kelly, E.F., Blecker, S.W., Yonker, C.M., Olson, C.G., Wohl, E.E., Todd, L.C., 1998. Stable isotope composition of soil organic matter and phytoliths as paleoenvironmental indicators. Biogeochemistry of isotopes in soil environments: theory and application. Geoderma 82, 58-81.

Kondo, R., Childs, C., Atkinson, I., 1994. Opal phytoliths of New Zealand. Manaaki Whenua Press. 85 pp.

Krull, E.S., Baldock, J.A., Skjemstad, J.O., 2003a. Importance of mechanisms and processes of the stabilisation of soil organic matter for modelling carbon turnover. Functional Plant Biology 30 (2), 207-222.

Krull, E.S., Skjemstad, J.O., Graetz, D., Grice, K., Dunning, W., Cook, G., Parr, J.F., 2003b. 13C-depleted charcoal from C4 grasses and the role of occluded carbon in phytoliths. Organic Geochemistry 34 (9), 1337-1352.

Le Cohu, M.-C., 1973. Examen au Microscope Electronique à Balayage des cônes de silice chez les Cypéracées. Compte Rendu de l'académie Des Sciences, Paris, 277, 130-133.

Liu, W., Huang, Y., An, Z., Clemens, S.C., Li, L., Prell, W.L., Ning, Y., 2005. Summer monsoon intensity controls $\mathrm{C} 4 / \mathrm{C} 3$ plant abundance during the last $35 \mathrm{ka}$ in the Chinese Loess Plateau: carbon isotope evidence from bulk organic matter and individual leaf waxes. Palaeogeography, Palaeoclimatology, Palaeoecology 220 (3-4), 243-254.

Livingstone, D.A., Clayton, W.D., 1980. An altitudinal cline in tropical African grass floras and its paleoecological significance. Quaternary Research 13, $392-402$.

Lu, H., Liu, K.B., 2003. Phytoliths of common grasses in the coastal environments of southeastern USA. Estuarine, Coastal and Shelf Science 58, 587-600.

Lu, H., Wu, N., Nie, G., 1995. Discovery of bamboo phytolith in the loesspaleosol sequences of Guanzhong Basin, Shaanxi Province. Chinese Science Bulletin 40 (5), 405-409.

Madella, M., Alexandre, A., Ball, T., ICPN Working Group, 2005. International Code for Phytolith Nomenclature 1.0. Annals of Botany 96 (2), 253-260.

McClaran, M.P., Umlauf, M., 2000. Desert grassland dynamics estimated from carbon isotopes in grass phytoliths and soil organic matter. Journal of Vegetation Science 11, 71-76.

McKone, D.A.V.W., 1994. A brief survey of Mbeya Region catchment forest reserves, Government of Tanzania/EEC Agroforestry, Soil and Water Conservation Project/Regional Natural Resources Office, Mbeya. Retrieved (2003) from: http://www.mckone.org/.

McKone, D., 1995. A Brief Survey of the Traditional Forest Reserves of Rungwe District, Mbeya Region, Tanzania. Unpublished Draft Report,
Government of Tanzania/EEC Agroforestry, Soil and Water Conservation Project, Mbeya and District Forestry Office, Rungwe District, Retrieved (2003) from: http://www.mckone.org/.

Mulholland, S.C., 1989. Phytoliths shape frequencies in North Dakota grasses: A comparison to general patterns. Journal of Archaeological Science 16, 489-511.

Mworia-Maitima, J., 1997. Prehistoric fires and land-cover change in Western Kenya: evidence from pollen, charcoal, phytoliths, and grass cuticle analyses. Holocene 7, 409-417.

Ollendorf, A.L., 1987. Archeological implications of a phytolith study at Tel Miqne (Ekron), Israel. Journal of Field Archaeology 14, 453-463.

Palmer, P.G., Gerbeth-jones, S., Hutchison, S., 1985. A scanning electron microscope survey of the epidermis of East African grasses, III. Smithsonian Contribution to Botany, vol. 55. Smithsonian Institution, Washington. 135 pp.

Piperno, D.P., 1988. Phytolith analysis - An archaeological and geological perspective. Academic Press / Harcourt Brace Jovanovich, New York (US). 1988. - 1 volume: 280 pp.

Piperno, D.R., Pearsall, D.M., 1998. The silica bodies of tropical American grasses: Morphology, taxonomy, and implications for grass systematics and fossil phytolith identification. Smithsonian Contributions to Botany 85, $1-40$

Prebble, M., Schallenberg, M., Carter, J., Shulmeister, J., 2002. An analysis of phytolith assemblages for the quantitative reconstruction of late Quaternary environments of the Lower Taieri Plain, otago, South Island, New Zealand I. Modern assemblages and transfer functions. Journal of Paleolimnology 27 (4), 393-413

Prentice, I.C., Webb, T., 1998. BIOME 6000: reconstructing global midHolocene vegetation patterns from palaeoecological records. Journal of Biogeography 25, 997-1005.

Prentice, I.C., Cramer, W., Harrison, S.P., Leemans, R., Monserud, R.A., Solomon, A.M., 1992. A global biome model based on plant physiology and dominance, soil properties and climate. Journal of Biogeography 19, 117-134.

Runge, F., 1999. The opal phytolith inventory of soils in central Africaquantities, shapes, classification, and spectra. Review of Palaeobotany and Palynology 107 (1-2), 23-53.

Runge, F., Fimbel, R., 1999. Opal phytoliths as evidence for the formation of savanna islands in the rain forest of Southeast Cameroon. In: Heine, K., Runge, G.E.J. (Eds.), International Union for Quaternary Research. Proceeding of the VXth INQUA Conference (15th:1999:Durban South Africa) - Palaeoecology of Africa and the surrounding islands. Taylor \& Francis, Tokyo, pp. 171-189.

Sage, R.F., Wedin, D.A., Meirong, L., 1999. The biogeography of C4 photosynthesis: Patterns and controlling factors. In: Sage, R.F., Monson, R.K. (Eds.), C4 Plant Biology. Academic Press, Toronto. 596 pp.

Scott, L., 2002. Grassland development under glacial and interglacial conditions in southern Africa: review of pollen, phytolith and isotope evidence. Palaeogeography, Palaeoclimatology, Palaeoecology 177 (1-2), 47-57.

Scurfield, G., Anderson, C.A., Segnit, E.R., 1974. Silica in woody stems. Australian Journal of Botany 22, 211-229.

Sitch, S., Smith, B., Prentice, I.C., Arneth, A., Bondeau, A., Cramer, W., Kaplan, J.O., Levis, S., Lucht, W., Sykes, M.T., Thonicke, K., Venevsky, S., 2003. Evaluation of ecosystem dynamics, plant geography and terrestrial carbon cycling in the LPJ dynamic global vegetation model. Global Change Biology 9 (2), 161-185.

Smith, F.A., White, J.W.C., 2004. Modern calibration of phytolith carbon isotope signatures for $\mathrm{C} 3 / \mathrm{C} 4$ paleograssland reconstruction. Palaeogeography, Palaeoclimatology, Palaeoecology 207 (3-4), 277-304.

Street-Perrott, F.A., Ficken, K.J., Huang, Y.S., Eglinton, G., 2004. Late quaternary changes in carbon cycling on Mt. Kenya, East Africa: an overview of the delta d13C record in lacustrine organic matter. Quaternary Science Reviews 23 (7-8), 861-879

Strömberg, C.A.E., 2002. The origin and spread of grass-dominated ecosystems in the late Tertiary of North America: preliminary results concerning the evolution of hypsodonty. Palaeogeography, Palaeoclimatology, Palaeoecology $177(1-2), 59-75$.

Strömberg, C.A.E., 2004. Using phytolith assemblages to reconstruct the origin and spread of grass-dominated habitats in the great plains of North America during the late Eocene to early Miocene. Palaeogeography Palaeoclimatology Palaeoecology 207 (3-4), 239-275. 
Tattersfield, P., Warui, C.M., Seddon, M.B., Kiringe, J.W., 2001. Land-snail faunas of afromontane forests of Mount Kenya, Kenya: ecology, diversity and distribution patterns. Journal of Biogeography 28 (7), 843-861.

Tieszen, L.L., Senyimba, M.M., Imbamba, S.K., 1979. The distribution of C3 and $\mathrm{C} 4$ grasses and carbon isotope discrimination along a altitudinal and moisture gradient in Kenya. Oecologia 37, 337-350.

Twiss, P.C., 1992. Predicted world distribution of C3 and C4 grass phytoliths. In: Rapp, G.R., Mulholland, S.C. (Eds.), Phytoliths systematics: emerging issues. Advance Archaeological Museum Science, vol. 1. Plenum Press, New York, pp. 113-128.

Twiss, P.C., Suess, E., Smith, R.M., 1969. Morphological classification of grass phytoliths. Procedure of Soil Science Society of America 33, 109-115.

Vrydaghs, L., Doutrelepont, H., 2000. Analyses phytolithariennes: acquis et perspectives. In: Servant-Vildary, S., Servant, M. (Eds.), Dynamiques à long terme des écosystèmes forestiers intertropicaux. UNESCO, Paris.

Wallis, L., 2003. An overview of leaf phytolith production patterns in selected northwest Australian flora. Review of Palaeobotany and Palynology $125(3-4)$, 201-248.

Wass, P. (Ed.), 1995. Kenya's Indigenous Forests - Status, Management and Conservation. IUCN Forest Conservation Programme. IUCN, Gland, Switzerland and Cambridge, UK, in collaboration with ODA (135 pp.).

Watson, L., Dallwitz, M.J., 1992. Grass Genera of the World: Descriptions, Illustrations, Identification, and Information Retrieval; including Synonyms, Morphology, Anatomy, Physiology, Phytochemistry, Cytology, Classification, Pathogens, World and Local Distribution, and References. http:// biodiversity.uno.edu/delta/.

Watson, L., Clifford, H.T., Dallwitz, M.J., 1985. The classification of Poaceae: Subfamilies and Supertribes. Australian Journal of Botany 33, 433-484.
White, F., 1983. The vegetation map of Africa. UNESCO, Paris. $356 \mathrm{pp}$

Williamson, D., Jackson, M.J., Banerjee, S.K., Marvin, J., Merdaci, O., Thouveny, N., Decobert, M., Gibert-Massault, E., Massault, M., Mazaudier, D., Taieb, M., 1999. Magnetic signatures of hydrological change in a tropical maar-lake (Lake Massoko, Tanzania): preliminary results. Physics and Chemistry of the Earth, Part A: Solid Earth and Geodesy 24 (9), 799-803.

Wooller, M.J., 1999. The palaeoecology of Mount Kenya: evidence from grasscuticle analysis. PhD Thesis, University of Wales, Swansea.

Wooller, M.J., 2002. Fossil grass cuticles from lacustrine sediments: a review of methods applicable to the analysis of tropical African lake cores. Holocene 12 (1), 97-105.

Wooller, M.J., Street-Perrot, F.A., Agnew, A.D.Q., 2000. Late Quaternary fires and grassland palaeoecology of Mount Kenya, East Africa: evidence from charred grass cuticules in lake sediments. Palaeogeography, Palaeoclimatology, Palaeoecology 164, 207-230.

Wooller, M.J., Swain, D.L., Street-Perrott, F.A., Mathai, S., Agnew, A.D.Q., 2001. An altitudinal and stable carbon isotope survey of $\mathrm{C} 3$ and $\mathrm{C} 4$ graminoids on Mount Kenya. Journal of East African Natural History 90, 69-85.

Wooller, M.J., Swain, D.L., Ficken, K.J., Agnew, A.D.Q., Street-Perrott, F.A., Eglinton, G., 2003. Late Quaternary vegetation changes around Lake Rutundu, Mount Kenya, East Africa: evidence from grass cuticles, pollen and stable carbon isotopes. Journal of Quaternary Science 18 (1), 3-15.

Wooller, M.J., Johnson, B.J., Wilkie, A., Fogel, M.L., 2005. Stable isotope characteristics across narrow savanna/woodland ecotones in Wolfe Creek Meteorite Crater, Western Australia. Oecologia 145 (1), 100-112.

Young, H.J., Young, T.P., 1983. Local distribution of C3 and C4 grasses in sites of overlap on Mount Kenya. Oecologia 58, 373-377 (Berlin). 